Article

\title{
Comparative Analysis of Soybean Root Proteome Reveals Molecular Basis of Differential Carboxylate Efflux under Low Phosphorus Stress
}

\author{
Krishnapriya Vengavasi ${ }^{1,+}$, Renu Pandey ${ }^{1, *}$ (D), Gerard Abraham ${ }^{2}$ and Ravindra Kumar Yadav ${ }^{2}$ \\ 1 Mineral Nutrition Laboratory, Division of Plant Physiology, ICAR-Indian Agricultural Research Institute, \\ New Delhi 110012, India; krishnapriya19@gmail.com \\ 2 National Centre for Conservation and Utilization of Blue Green Algae, Division of Microbiology, \\ ICAR-Indian Agricultural Research Institute, New Delhi 110012, India; gabraham@iari.res.in (G.A.); \\ ravindrabga@gmail.com (R.K.Y.) \\ * Correspondence: renu_iari@rediffmail.com; Tel.: +91-11-2584-2815 \\ † Present address: ICAR-Sugarcane Breeding Institute, Coimbatore 641007, India.
}

Received: 9 October 2017; Accepted: 20 November 2017; Published: 30 November 2017

\begin{abstract}
Carboxylate efflux from roots is a crucial and differential response of soybean genotypes to low phosphorus $(\mathrm{P})$ stress. Exudation of carboxylic acids including oxalate, citrate, succinate and fumarate was induced under low P stress, particularly in P-efficient soybean genotypes. Enhancement of root length, surface area and volume further improved $\mathrm{P}$ acquisition under low $\mathrm{P}$ stress. To understand the molecular basis of carboxylate efflux under low $\mathrm{P}$ stress, the root proteome of contrasting genotypes (P-efficient: EC-232019 and P-inefficient: EC-113396) was compared. Among a total of 325 spots, 105 (32\%) were differentially abundant proteins (DAPs) between sufficient $(250 \mu \mathrm{M})$ and low $\mathrm{P}(4 \mu \mathrm{M})$ levels. Abundance of $44(14 \%)$ proteins decreased by more than two-fold under low P stress, while 61 (19\%) proteins increased by more than two-fold. Protein identification and annotation revealed that the DAPs were involved in a myriad of functions including carboxylic acid synthesis, carbohydrate, protein and lipid metabolism. Proteins with significant abundance included malate dehydrogenase, isocitrate dehydrogenase, phosphoglucomutase, phosphoglycerate mutase, fructokinase, enolase, phosphoglycerate kinase, triosephosphate isomerase, alcohol dehydrogenase, glucan water dikinase, glutamine synthetase and argininosuccinate lyase. Inferences from proteomic analysis suggests the crosstalk between various metabolic pathways implicated in conferring superior $P$ acquisition efficiency under stress.
\end{abstract}

Keywords: carboxylate efflux; gene expression analysis; Glycine max; mass spectrometry; phosphorus stress; root proteome; two-dimensional gel electrophoresis

\section{Introduction}

Phosphorus (P) is an essential element for plant growth and development, with structural (nucleic acids, phospholipids), metabolic (energy transfer) and regulatory functions. P nutrition positively affects crop growth, with significant influence on above- (leaf area, dry matter accumulation, leaf $\mathrm{P}$ content, photosynthesis) and below-ground (root morphological traits, root exudation, symbiotic association) processes [1]. In soybean (Glycine max (L.) Merr.), P nutrition is important owing to its direct effect on growth and morphological responses and indirectly influencing nodulation and $\mathrm{N}_{2}$-fixation, and ultimately yield. Cultivating P-efficient soybean genotypes that can utilize the unavailable forms of soil P might be a sustainable option to increase crop productivity in the face of dwindling P reserves.

Altered root architecture and morphology, along with increased synthesis and excretion of carboxylic acids is crucial to enhance P acquisition [2-4]. Carboxylate ions release P from 
Al-P/Fe-P/Ca-P complexes by ligand exchange [5]. Low P stressed alfalfa (Medicago sativa) showed higher exudation of citrate, malate and fumarate ions compared to P sufficient plants [6]. Substantial amounts of malonic, succinic, fumaric, malic and citric acid were detected in root exudate of several $\mathrm{P}$ starved legumes [7]. Higher exudation of malate, oxalate and citrate exhibited by P-efficient soybean genotypes during $\mathrm{P}$ deficiency resulted in better growth traits compared to P-inefficient ones [8]. Higher citrate exudation helped P-efficient rice genotypes to mobilize P from sparingly soluble sources [9]. Root exudation in green gram (Vigna radiata) genotypes showed a positive association with biomass and $P$ uptake [10].

Most common carboxylates in root exudates (citrate, malate, malonate, acetate, fumarate, succinate, lactate and oxalate) [11] are involved in respiration, stomatal regulation and other metabolic pathways, hence their efflux is primarily influenced by activity of glycolytic and tricarboxylic acid pathways [5]. Rate of exudation is a function of higher concentration of carboxylic acids in the cytosol as well as the expression and activation of efflux transporters/anion channels in the plasma membrane of root cells [12]. Members of the aluminum-activated malate transporter (ALMT) and multidrug and toxic compound extrusion (MATE) membrane protein families mediate malate and citrate efflux, respectively [13]. Earlier reports on efflux transporters in wheat (Triticum aestivum) TaALMT1 [14] and TaMATE1 [15] suggested that their expression was induced by aluminum toxicity. Overexpression of TaALMT1 in barley improved P acquisition on acidic soils [16] confirming that $\mathrm{P}$ deficiency also induced expression of transporter proteins to facilitate carboxylate exudation. Liang and co-workers [17] isolated and characterized a malate efflux transporter from soybean GmALMT1, which was regulated by low $\mathrm{pH}$, aluminum and $\mathrm{P}$ supply. In soybean, efflux transporters for malate (GmALMT1) and citrate (GmMATE) have been identified till date. Search for the missing players (genes/proteins) regulating synthesis and efflux of other carboxylic acids may enhance our knowledge in improving P uptake efficiency of soybean and related crops.

Transcriptomic, proteomic and metabolomic analysis of different tissues subjected to varying levels and combinations of stress aid in identifying the molecular determinants of stress response mechanisms in plants. Among these, proteomic approaches are more robust as it is based on the expressed gene product. Proteome analyses to determine adaptation strategies to low $\mathrm{P}$ stress have been conducted in several crops such as maize (Zea mays) [18], oilseed rape (Brassica napus) [19] and Arabidopsis thaliana [20]. Comprehensive reference maps of soybean proteome [21-23] would accelerate the process of developing low P stress efficient soybean cultivars. Alterations to soybean proteome at the tissue and organelle level have been investigated under several abiotic stresses such as flooding, drought, salinity, aluminum and cadmium toxicity at different stages of crop growth [24,25]. However, influence of low $\mathrm{P}$ stress on soybean proteome, particularly in genotypes with contrasting root phenotypes and carboxylate exudation capacity has not been reported till date. To address this aspect, we conducted experiments employing a diverse panel of 116 soybean genotypes, to identify those with contrasting root exudation potential at low P compared to sufficient P [26]. Phenotyping for growth response and carboxylate efflux led to identification of EC-232019 (P-efficient) and EC-113396 (P-inefficient) with contrasting root exudation potential at low P stress [27]. In this paper, we present the results of comparative proteome analysis in root tissues of EC-232019 and EC-113396 grown at sufficient $(250 \mu \mathrm{M})$ and low $(4 \mu \mathrm{M}) \mathrm{P}$ level, which revealed several differentially abundant proteins (DAPs) under low P stress.

\section{Materials and Methods}

\subsection{Plant Material and Growth Conditions}

Soybean seeds of contrasting genotypes, EC-232019 (P-efficient) and EC-113396 (P-inefficient) were obtained from ICAR-Indian Institute of Soybean Research, Indore and Division of Genetics, ICAR-Indian Agricultural Research Institute, New Delhi, India, respectively. The seeds were surface sterilized with $0.1 \%(w / v) \mathrm{HgCl}_{2}$ and wrapped in germination towels moistened with $1 \mathrm{mM} \mathrm{CaCl}$. 
Upon emergence of cotyledonary leaf, seedlings were transferred to nutrient solution with two $\mathrm{P}$ levels: sufficient $(250 \mu \mathrm{M})$ and low $\mathrm{P}(4 \mu \mathrm{M})$. Seedlings were supported on a $5 \mathrm{~cm}$ thick styrofoam sheet at a spacing of $3 \mathrm{~cm} \times 3 \mathrm{~cm}$. The cotyledonary leaves were removed on third day of transfer to nutrient solution to minimize genotypic variation due to seed $P$ content. Thirty-six such seedlings were accommodated in individual containers. Three replications with four seedlings each were maintained for all treatment combinations. Styrofoam sheet was placed in a plastic container with $10 \mathrm{~L}$ of basal nutrient solution. Composition of the nutrient solution was as described in Vengavasi et al. [27], and pH was maintained at 6.5 using either $1.0 \mathrm{~N} \mathrm{HCl}$ or $1.0 \mathrm{~N} \mathrm{KOH}$. The solution was aerated continuously and renewed every third day. The experiment was conducted in greenhouse at the National Phytotron Facility, ICAR-IARI, New Delhi, India with day/night temperature of $30 / 26^{\circ} \mathrm{C}$, photoperiod of $12 \mathrm{~h}$ at a photon flux density of $850 \mu \mathrm{mol} \cdot \mathrm{m}^{-2} \cdot \mathrm{s}^{-1}$ and relative humidity of $85 \%$.

\subsection{Growth Traits and Tissue Phosphorus Status}

Roots of 20-d-old plants were scanned using root scanner (Regent Instruments Inc., Québec, QC, Canada) (Figure S1A) and the images were analyzed in WinRhizo Pro software (Regent Instruments, Ville de Québec, QC, Canada) to obtain total root length ( $\mathrm{cm}^{\text {plant }}{ }^{-1}$ ), surface area $\left(\mathrm{cm}^{2}\right.$ plant $\left.{ }^{-1}\right)$, volume $\left(\mathrm{cm}^{3}\right.$ plant $\left.{ }^{-1}\right)$ and number of root tips. Root and shoot $\mathrm{P}$ concentration ( $\mu \mathrm{g} \mathrm{g}^{-1}$ dry weight (DW)) was determined by ascorbic acid method [28] after digestion of dried tissue with di-acid mixture $\left(\mathrm{HNO}_{3}: \mathrm{HClO}_{3}:: 9: 4\right)$. Tissue $\mathrm{P}$ content was calculated from $\mathrm{P}$ concentration in root or shoot, the sum of which was the total $\mathrm{P}$ uptake, expressed as $\mu \mathrm{g} \mathrm{P} \mathrm{plant}{ }^{-1}$.

\subsection{Collection and Quantification of Root Carboxylate Efflux}

Twenty-d-old plants were placed in $100 \mathrm{~mL}$ Erlenmeyer flasks with their roots immersed well in $50 \mathrm{~mL}$ of trap solution $\left(0.5 \mathrm{mM} \mathrm{CaCl}_{2}, \mathrm{pH} 4.5\right)$ (Figure S1B). The flasks were covered with black paper and exudates were collected from 08:00 to 12:00 h. Roots were washed in deionized water and blotted dry to determine fresh weight. The exudates were passed through Whatman no. 1 filter paper and frozen immediately to avoid microbial degradation. Root exudate was processed [26] and quantified through high-performance liquid chromatography (HPLC) (Agilent 1200 Infinity, Agilent Technologies, Palo Alto, CA, USA) with Hi-Plex $\mathrm{H}$ column as the stationary phase. The column temperature was set at $70{ }^{\circ} \mathrm{C}$. Mobile phase $\left(0.005 \mathrm{M} \mathrm{H}_{2} \mathrm{SO}_{4}\right)$ was used at a flow rate of $0.6 \mathrm{~mL} \mathrm{~min}^{-1}$. Individual samples were run for $25 \mathrm{~min}$ and peaks captured by a refractive index detector with an optical temperature of $55^{\circ} \mathrm{C}$. Concentration of acids was quantified from the calibration curves of standards and expressed in $\mu \mathrm{mol} \mathrm{g}^{-1}$ root fresh weight.

\subsection{Protein Isolation and Quantification}

Two g of root tissue was finely ground using liquid nitrogen in a pre-chilled pestle and mortar. Fifteen $\mathrm{mL}$ of extraction buffer containing $50 \mathrm{mM}$ 2-[4-(2-hydroethyl)piperazin-1-yl] ethanesulfonic acid (HEPES) $\mathrm{pH} 7.5,40 \%(w / v)$ sucrose and $0.1 \%(v / v) \beta$-mercaptoethanol was added to the root powder and thoroughly homogenized. The homogenate was transferred to an Oak-ridge tube and $15 \mathrm{~mL}$ of phenol (equilibrated with $10 \mathrm{mM}$ Tris $\mathrm{pH} 8.0$ and $1 \mathrm{mM}$ Ethylene diamine tetraacetic acid (EDTA) was added to it. After thorough mixing for $30 \mathrm{~min}$, the homogenate was centrifuged at $5000 \mathrm{rpm}$ for $10 \mathrm{~min}$ at $4{ }^{\circ} \mathrm{C}$. Phenol phase was transferred to a fresh Oak-ridge tube to which $40 \mathrm{~mL}$ of precipitation buffer $(0.1 \mathrm{M}$ ammonium acetate in $100 \%(v / v)$ methanol) was added and incubated overnight at $-20^{\circ} \mathrm{C}$. The protein pellet was obtained by centrifugation at $15,000 \mathrm{rpm}$ for $30 \mathrm{~min}$ at $4{ }^{\circ} \mathrm{C}$. The pellet was washed with $40 \mathrm{~mL}$ of $80 \%(v / v)$ acetone by vortexing and centrifuged at 15,000 rpm for $30 \mathrm{~min}$ at $4{ }^{\circ} \mathrm{C}$. Washing step was repeated thrice after which the pellet was evaporated to dryness in a vacuum evaporator and stored at $-80^{\circ} \mathrm{C}$ until further analysis.

For quantification of protein, the pellet was dissolved in a solubilization cocktail containing $7 \mathrm{M}$ urea, $2 \mathrm{M}$ thiourea, $2 \%(w / v) 3$-[(3-Cholamidopropyl) dimethylammonio]-1-propanesulfonate hydrate (CHAPS), $400 \mathrm{mM}$ dithiothreitol (DTT), and 1\% (v/v) ampholyte (Biolyte $\mathrm{pH} 4-7)$. After $1 \mathrm{~h}$ of gentle 
stirring at room temperature, samples were centrifuged at $15,000 \mathrm{rpm}$ for $30 \mathrm{~min}$ at $4{ }^{\circ} \mathrm{C}$ to remove the precipitated nucleic acids. Supernatants were transferred to fresh $1.5 \mathrm{~mL}$ Eppendorf tube and protein concentration was determined by Bradford method [29]. Protein quality was checked by subjecting all samples to sodium dodecyl sulfate polyacrylamide gel electrophoresis (SDS-PAGE) (Figure S2).

\subsection{Two-Dimensional Gel Electrophoresis and Image Analysis}

Immobilized pH gradient (IPG) strips (ReadyStrip ${ }^{\mathrm{TM}}$, BioRad, Hercules, CA, USA) of $11.0 \mathrm{~cm}$ with $\mathrm{pH} 4$ to 7 were passively rehydrated overnight with $400 \mu \mathrm{g}$ of protein. Isoelectric focusing was performed in the Protean i12 IEF cell (BioRad, Hercules, CA, USA) with the following program: 200 volts for $180 \mathrm{~min}, 500$ volts for $30 \mathrm{~min}, 1000$ volts for $30 \mathrm{~min}, 6000$ volts for $60 \mathrm{~min}, 6000$ volts until a total of 3000 volt-hours followed by 500 volts for $20 \mathrm{~h}$. After completion of isoelectric focusing, the strips were equilibrated for 15 min each in reducing buffer containing $50 \mathrm{mM}$ Tris-HCl ( $\mathrm{pH} 8.8), 6 \mathrm{M}$ urea, $30 \%(v / v)$ glycerine, $2 \%(w / v)$ SDS and $20 \mathrm{mM}$ DTT followed by alkylation buffer composed of $50 \mathrm{mM}$ Tris-HCl ( $\mathrm{pH} 8.8), 6 \mathrm{M}$ urea, 30\% (v/v) glycerine, 2\% ( $w / v)$ SDS and $135 \mathrm{mM}$ Iodoacetamide. Separating gel containing $12 \%(w / v)$ acrylamide, $375 \mathrm{mM}$ Tris- $\mathrm{HCl}(\mathrm{pH} 8.8), 0.1 \%(w / v)$ ammonium persulfate and $0.04 \%$ Tetramethylethylenediamine (TEMED) was poured into gel slabs. After polymerization, the equilibrated IPG strips were loaded on to the separating gel along with a protein ladder (11 to $245 \mathrm{kDa}$ ) placed at the corner well. The gels were overlaid with $1 \%(w / v)$ agarose (containing $0.1 \%(w / v)$ Bromophenol Blue tracking dye). Separation was performed at $13^{\circ} \mathrm{C}$ with a constant current of $25 \mathrm{~mA}$ per gel in a Protean II xi cell (BioRad, Hercules, CA, USA) electrophoresis system. When tracking dye reached the base of the gel, the current was terminated. Gels were washed with deionized water and incubated overnight in staining solution containing $10 \%(v / v)$ acetic acid, $40 \%(v / v)$ methanol and $0.1 \%(w / v)$ Coomassie Brilliant Blue G-250. After staining, the gels were placed in destaining solution containing $7 \%(v / v)$ acetic acid and 25\% $(v / v)$ methanol until the background was clear and protein spots visible.

Image of gels were digitized in a densitometer (ImageScanner III, GE Healthcare Bio-Sciences, Uppsala, Sweden) for analysis based on spot density and location (Figure S3). Image analysis was performed with PDQuest software version 8.0.1 (BioRad, Hercules, CA, USA). Spots were quantified on the basis of their relative volume which was determined by the ratio of the volume of a single spot to the whole set of spots under low P stress. Spots with significant (more than two-fold differential expression, $\alpha=0.05$ by Student's $t$-test) and reproducible changes in three replicates were used for further analysis.

\subsection{Trypsin Digestion of Proteins}

The protein spots of interest were picked from the gels, washed twice with MilliQ water, followed by $50 \%(v / v)$ acetonitrile. To this, $100 \mu \mathrm{L}$ of $10 \mathrm{mM}$ DTT dissolved in $25 \mathrm{mM}$ ammonium bicarbonate (reducing buffer) was added and incubated at $45^{\circ} \mathrm{C}$ for $60 \mathrm{~min}$. Reducing buffer was discarded and protein spots were incubated in dark for 15 min with $100 \mu \mathrm{L}$ of $10 \mathrm{mM}$ iodoacetamide dissolved in $25 \mathrm{mM}$ ammonium bicarbonate (alkylating buffer). This was followed by two sequential washing steps with $50 \%(v / v)$ and $100 \%(v / v)$ acetonitrile. The pellet was allowed to dry thoroughly and resuspended in $50 \mu \mathrm{L}$ of $10 \mu \mathrm{g} \mathrm{mL} \mathrm{m}^{-1}$ trypsin dissolved in $25 \mathrm{mM}$ ammonium bicarbonate and incubated overnight at $35{ }^{\circ} \mathrm{C}$. The supernatant was transferred to a fresh Eppendorf tube and lyophilized at $-80{ }^{\circ} \mathrm{C}$. Lyophilized peptides were suspended in $1 \%(w / v)$ tetrafluoroacetic acid in $50 \%(v / v)$ acetonitrile prior to mass spectrometry.

\subsection{Mass Spectrometry for Protein Identification}

The peptide mass fingerprints of DAPs were collected on an AB Sciex TOF/TOFTM 5800 system with Series Explorer 7000 (AB Sciex, Concord, ON, Canada). The parameters were set as follows: Digestion enzyme: trypsin (specificity: C-terminal to Arginine and Lysine) with one missed cleavage; fixed modification: Carbamidomethyl (C); Mass Spectrometry (precursor-ion) peak 
filtering: $800-4000 \mathrm{~m} / \mathrm{z}$ interval, monoisotopic, minimum signal-to-noise ratio (S/N) 10 , mass tolerance $250 \mathrm{ppm}$; database used: Viridiplantae taxonomic sub-database $(52,74,071$ sequences) of the National Centre for Biotechnology Information protein database (NCBIprot, release date 08-11-2017; 12,86,24,863 sequences). Peptide mass fingerprints were searched against the database using the online Mascot server (version 2.6.0, Matrix Science Limited, London, UK). Proteins with Mascot score greater than 80 were considered as significant $(P<0.05)$ hits.

\subsection{In-Silico Analysis for Protein Annotation}

Protein sequences identified from the Mascot search were functionally annotated using the bioinformatics platform Blast2GO [30] by assigning their associated generic Gene Ontology (GO) terms and Enzyme codes. This was based on homology to proteins from other species as determined by BLAST and the occurrence of InterPro functional domains identified by InterProScan. Annotations were further expanded using ANNEX [31]. BLAST searches were conducted for each protein (TBLASTX, nr database, report 20 hits, maximum e-value $1 \mathrm{E}^{-10}$ ), followed by mapping and annotation. The resulting GO terms were mapped onto the corresponding Plant GO Slim terms. The annotated enzymes were also assigned to their respective KEGG pathway maps [32].

\subsection{Validation of DAPs at Transcript Level by Reverse Transcription-qPCR}

Total RNA was isolated from root tissue with TRIzol reagent (Invitrogen) and quantified in Nanodrop1000 Spectrophotometer (Thermo Scientific, Waltham, MA, USA). Contamination by genomic DNA was removed by treating $10 \mu \mathrm{g}$ of RNA with DNase I (Promega). RNA integrity was verified in $1 \%(w / v)$ agarose gel stained with ethidium bromide and visualized under UV light in a gel documentation system (AlphaImager, Cell Biosciences, Heidelberg, Germany). cDNA was synthesized using SuperScript III reverse transcriptase (Invitrogen) according to the manufacturer's instructions. All samples were normalized to contain $50 \mathrm{ng} \cdot \mu \mathrm{L}^{-1}$ of cDNA confirmed by the amplification of the reference gene "elongation factor $1 \alpha^{\prime \prime}\left(G m_{-} E F 1 \alpha\right)$ and visualized on a $3 \%(w / v)$ agarose gel. Gene-specific primers (Table S1A,B) of proteins with significant Mascot scores were designed using the RealTime quantitative polymerase chain reaction (qPCR) tool of Integrated DNA Technologies [33]. Reverse transcription quantitative polymerase chain reaction (RT-qPCR) was carried out using the DyNAmoColorFlash SYBR Green I qPCR kit (Thermo Scientific, Waltham, MA, USA) on a Stratagene Mx3005P qPCR System (Agilent Technologies, Santa Clara, CA, USA). Reverse transcription-qPCR was performed in triplicate of $20 \mu \mathrm{L}$ reaction containing $10 \mu \mathrm{L}$ of $2 X$ SYBR Green I master mix, $0.12 \mu \mathrm{L}$ of 50X ROX passive reference dye, $1 \mu \mathrm{L}$ of forward primer $\left(0.5 \mathrm{pmol}_{\mu} \mathrm{L}^{-1}\right), 1 \mu \mathrm{L}$ of reverse primer $\left(0.5 \mathrm{pmol} \mu \mathrm{L}^{-1}\right), 1 \mu \mathrm{L}$ of cDNA template and $6.88 \mu \mathrm{L}$ of nuclease-free water. The cycling parameters were as follows: $10 \mathrm{~min}$ of pre-denaturation at $95^{\circ} \mathrm{C}, 40$ cycles of $30 \mathrm{~s}$ at $95^{\circ} \mathrm{C}$ and $30 \mathrm{~s}$ at $60^{\circ} \mathrm{C}$, followed by dissociation curve analysis $\left(1 \mathrm{~min}\right.$ at $95^{\circ} \mathrm{C}, 30 \mathrm{~s}$ at $55^{\circ} \mathrm{C}$ and ramp up to $95^{\circ} \mathrm{C}$ ). The MxPro software version 4.10 (Agilent Technologies, Santa Clara, CA, USA) was used for data collection. Melt curves were examined to detect inadvertent multiple amplicons. Primer specificity was also ensured by presence of single PCR product visualized on a 3\% $(w / v)$ agarose gel. The comparative cycle threshold method [34] was used to calculate relative transcript levels at experimental condition (low $\mathrm{P}$ ) with three reference genes: $60 S$ ribosomal subunit (Gm_60S), F-box (Gm_F-box) and GmEF1 $\alpha$. Negative controls were incorporated for each primer pair and individual PCR reactions were performed in triplicates.

\subsection{Experimental Design and Statistical Rationale}

All experiments were completely randomized with two factors: phosphorus level $(\mathrm{P})$ and genotype (G). Physiological experiments to measure growth, root traits and root exudation were technically replicated thrice $(n=9)$, while protein isolation and 2D separation was carried out once in each biological replicate $(n=3)$. For validation of gene expression, RNA was isolated from three biological replicates, and RT-qPCR was carried out in three technical replicates $(n=9)$. Procedures for descriptive statistics and analysis of variance ( $\alpha=0.001$ for physiological data; $\alpha=0.05$ for proteomics 
and expression validation) were carried out in the statistical software R version 3.1.2 (R Foundation for Statistical Computing, Vienna, Austria). Graphs and figures were plotted using GraphPad Prism version 6.00 (GraphPad Software, La Jolla, CA, USA).

\section{Results}

Soybean genotypes EC-232019 and EC-113396 responded differentially to low P stress, in terms of biomass accumulation, root system traits, uptake of $\mathrm{P}$ and carboxylate efflux as well as the root proteome profile. The salient results of the investigation are highlighted below.

\subsection{Biomass Accumulation, Root System Traits and Tissue PosphorusStatus}

$\mathrm{P}$ level, genotype and interactive effect of $\mathrm{P} \times$ genotype on total biomass and root-to-shoot ratio was significant $(P<0.001)$ (Table S2). Reduction in biomass was more prominent in EC-113396 compared to EC-232019 (Figure 1A). Biomass partitioning to the roots was higher in EC-232019 compared to EC-113396 under both sufficient and low P level (Figure 1B). P level had no significant effect on root-to-shoot ratio EC-232019, while there was a slight increase under low P in EC-113396. Significant genotypic variation was observed in root length, surface area and volume under low $\mathrm{P}$ stress (Table S2, Figure 1C-E). Low P stress increased root surface area by $106 \%$ and root volume by $85 \%$ in the EC-232019 whereas both traits were reduced by 50\% in EC-113396 at low P compared to sufficient $\mathrm{P}$. P level significantly $(\mathrm{P}<0.001)$ influenced tissue $\mathrm{P}$ status, with an overall reduction in shoot $(63 \%)$ and root $(73 \%)$ P concentrations at low P stress compared to sufficient P (Table S2, Figure 1F,G) in both genotypes. Irrespective of genotype, total P uptake was 70\% lower at low $\mathrm{P}$ as compared to sufficient $\mathrm{P}$ (Figure 1H), while EC-232019 exhibited least reduction (19\%) in total P uptake at low P compared to sufficient $\mathrm{P}$.

A
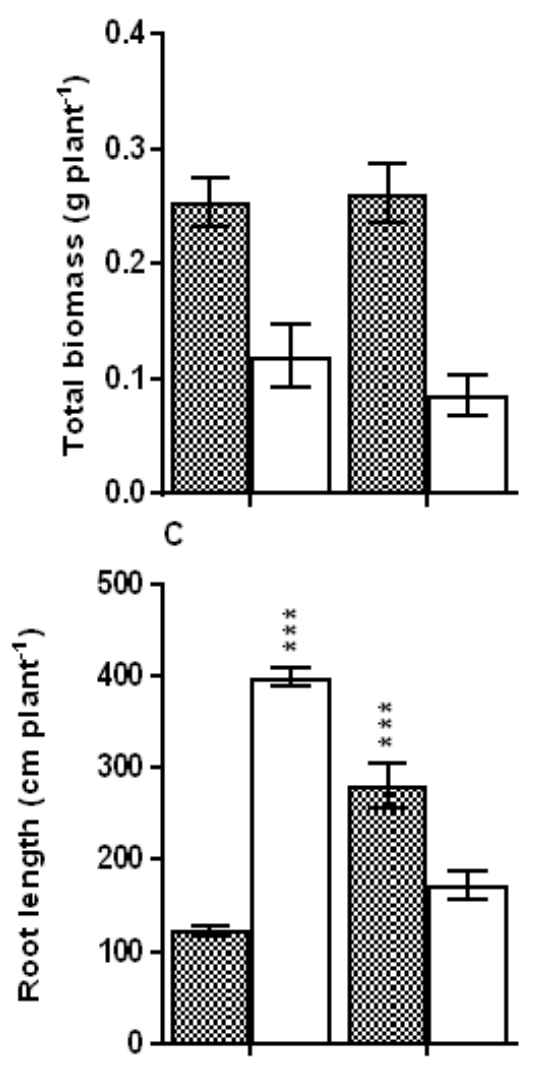

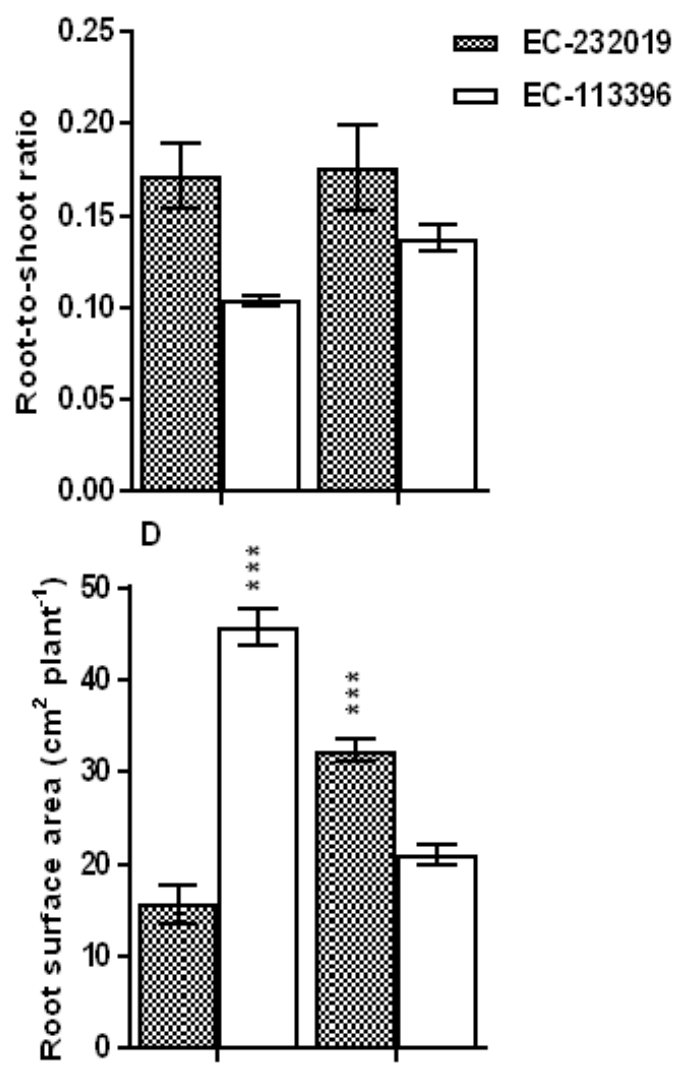

Figure 1. Cont. 

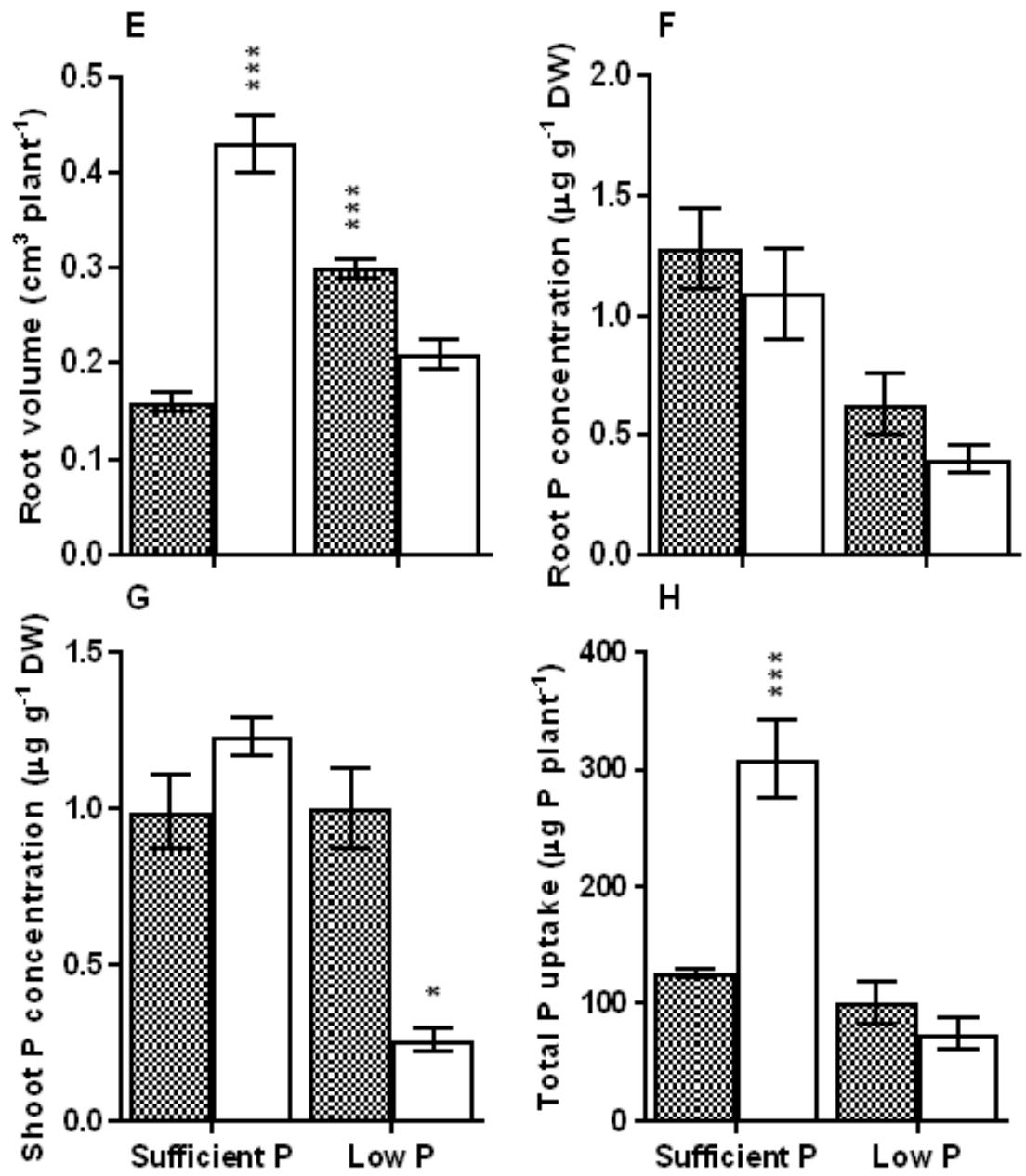

Figure 1. Variation in (A) total biomass, (B) root-to-shoot ratio, (C) root length, (D) root surface area, (E) root volume, $(\mathbf{F})$ root phosphorus $(\mathrm{P})$ concentration $(\mathrm{G})$ shoot $\mathrm{P}$ concentration and $(\mathbf{H})$ total $\mathrm{P}$ uptake in contrasting soybean genotypes grown at sufficient $(250 \mu \mathrm{M})$ and low $(4 \mu \mathrm{M}) \mathrm{P}$. Data correspond to mean \pm Standard Error $(n=9)$. DW: dry weight. ${ }^{*}, * *$ and ${ }^{* * *}$ denote significance at $0.05,0.01$ and 0.001 probability levels, respectively.

\subsection{Carboxylate Efflux in Response to Low Posphorus Stress}

Low P stress-induced carboxylate efflux differed both in type and quantity, and exhibited a significant $(P<0.001)$ variability among contrasting soybean genotypes (Table S2). Averaged over $P$ levels, EC-232019 exhibited higher rate of total carboxylate efflux compared to EC-113396. Low P induced-total carboxylate exudation increased by $58 \%$ in EC-232019, while it was reduced by $35 \%$ in EC-113396. In EC-232019, the efflux of oxalate, citrate, fumarate, succinate and lactate was induced under low $\mathrm{P}$ (Figure 2). Further, succinate and fumarate concentration in the root exudate increased by two-fold at low P in comparison to sufficient P in EC-232019. 

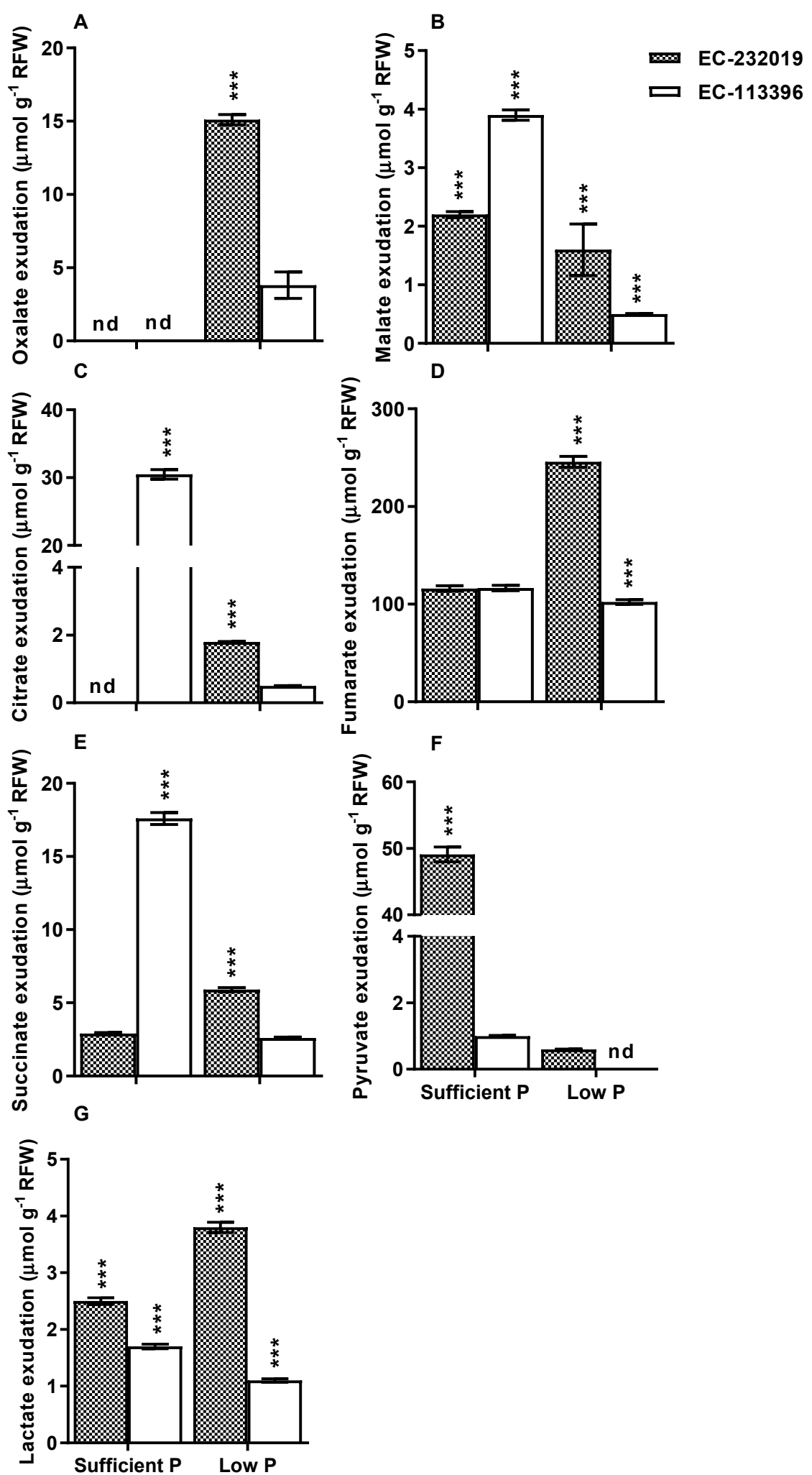

Figure 2. Variation in root exudation of (A) oxalate, (B) malate, (C) citrate, (D) fumarate, (E) succinate, (F) pyruvate and $(\mathrm{G})$ lactate in contrasting soybean genotypes grown at sufficient $(250 \mu \mathrm{M})$ and low $(4 \mu \mathrm{M})$ P. Data correspond to mean \pm SE $(n=9)$. "nd" denotes peak "not detectable". RFW: Root fresh weight. * ${ }^{* *}$ and ${ }^{* * *}$ denote significance at $0.05,0.01$ and 0.001 probability levels, respectively. 


\subsection{Comparative Analysis of Soybean Root Proteome}

Staining of two-dimensional electrophoretic gels using Coomassie Brilliant Blue dye revealed a total of 325 protein spots in the root tissue of EC-232019 and EC-113396 at low and sufficient P (Figure S3). Out of these, 105 (32\%) DAPs were observed between sufficient and low P levels (Figure 3A). A total of $44(14 \%)$ proteins decreased by more than two-fold under low P stress, while $61(19 \%)$ proteins increased by more than two-fold at low P. These 105 DAP spots were picked from the gels, digested with trypsin and sequenced by matrix-assisted laser desorption/ionization (MALDI) to obtain the peptide mass fingerprints. Annotated spectra of the DAP spots are provided in Datasets S1 and S2.

\subsubsection{Differentially Abundant Proteins in Response to Low Posphorus Stress}

Functional annotation of the DAPs based on gene ontology revealed their involvement in a myriad of biological processes including biosynthetic pathways, generation of precursor metabolites and energy, carbohydrate, protein and lipid metabolism (Figure 3B), localized to different cellular components (Figure 3C). Out of 61 increased proteins at low P, 27 were specific to EC-232019, 16 increased only in EC-113396 and 18 were common to both genotypes (Table 1). Eighteen peptide sequences with significant Mascot scores were derived from taxonomic databases of soybean (G. max) or its wild relative (G. soja). Some of the proteins significantly increased at low P condition were phosphoglycerate mutase, malate dehydrogenase, fructokinase, phosphoglucomutase, cysteine synthase, actin, $70 \mathrm{kDa}$ heat shock-related protein, heat shock cognate protein, proteasome, ATP synthase, isoflavone reductase and monodehydroascorbate reductase (Figure 4). Among the proteins with decreased at low $\mathrm{P}$, six were common to both genotypes, while 24 and 14 were specific to EC-232019 and EC-113396, respectively (Table 2). Twenty-three peptide sequences with significant Mascot scores were soybean (G. max) homologs. Twenty-two proteins were predicted from plant genome sequences, six were hypothetical and six uncharacterized or unknown proteins. Proteins decreased at low P included triosephosphate isomerase, phosphogluconate dehydrogenase, enolase, methionine synthase, chalcone isomerase, isocitrate dehydrogenase, glutathione-S-transferase, heat shock protein $70 \mathrm{kDa}$ and alcohol dehydrogenase (Figure 5). 


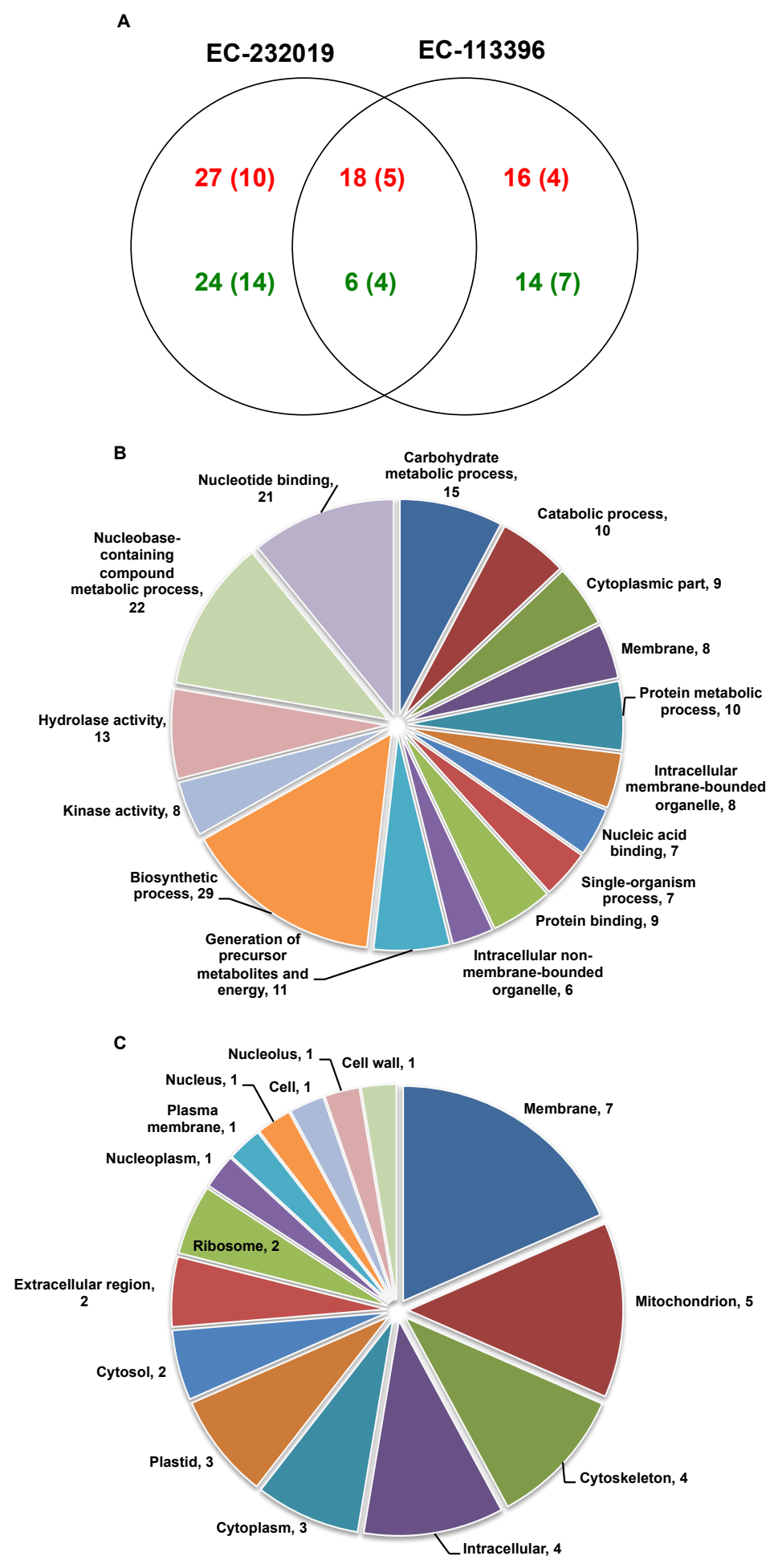

Figure 3. (A) Venn diagram showing number of differentially abundant proteins on two-dimensional electrophoretic gels at low $\mathrm{P}$ condition in comparison to sufficient $\mathrm{P}$. Number indicated in green color are decreased proteins at low $\mathrm{P}$, while red color are increased proteins at low P. Numbers within parenthesis correspond to proteins with significant Mascot score. Distribution of differentially abundant proteins based on gene ontology with respect to $(\mathbf{B})$ biological process and $(\mathbf{C})$ cellular localization. 


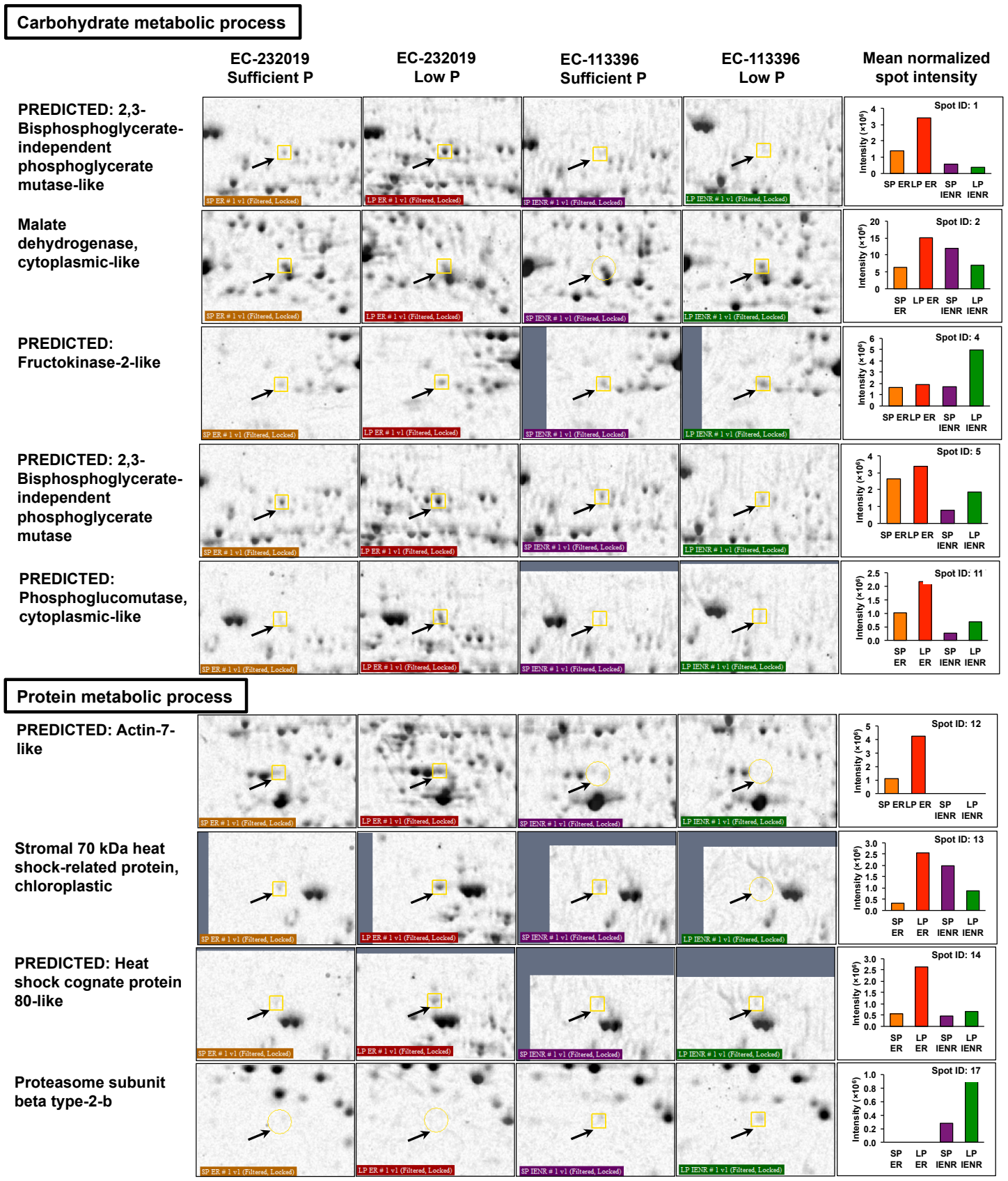

Figure 4. Cont. 


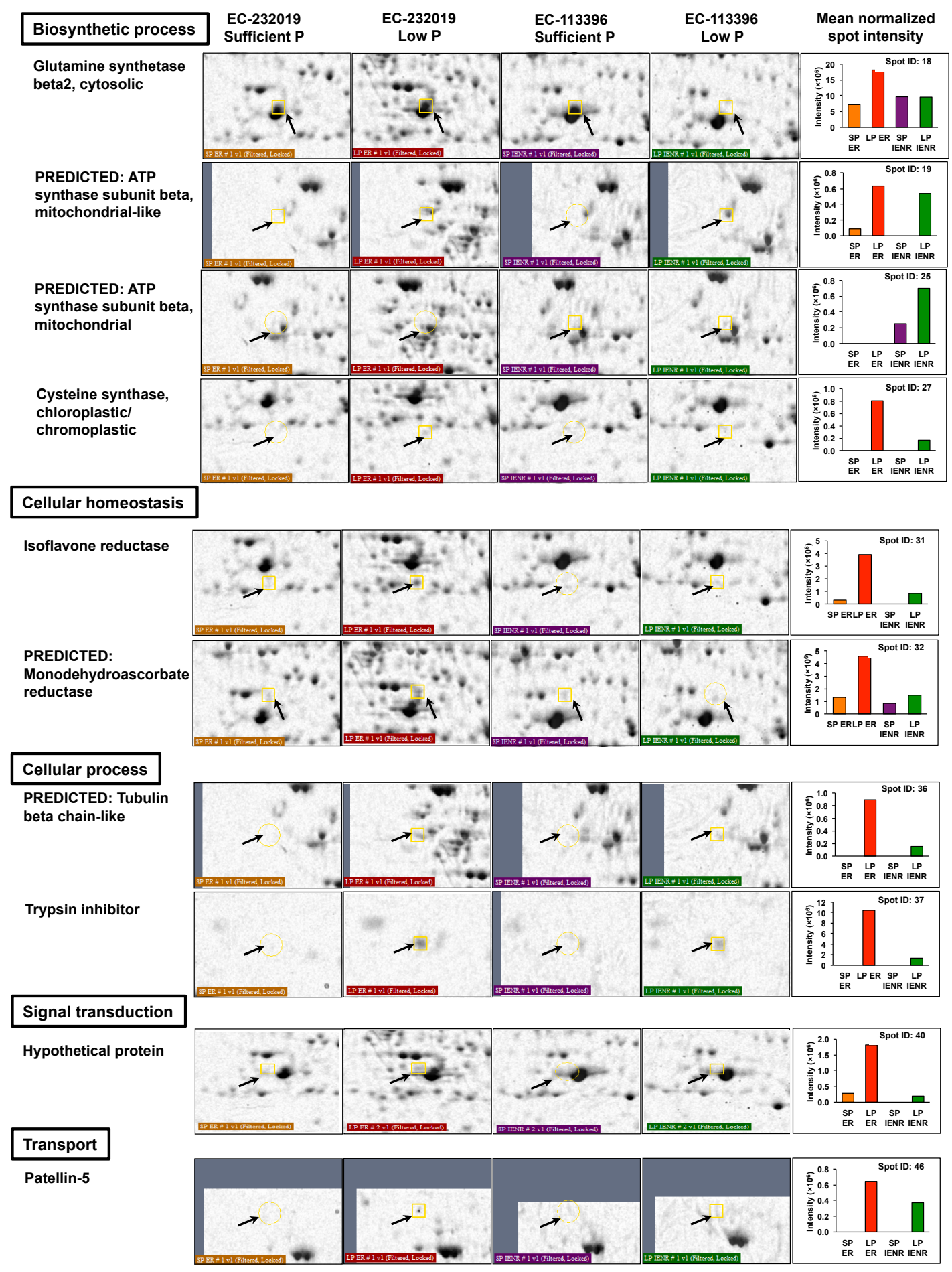

Figure 4. Root proteins increased by more than two-fold at low $(4 \mu \mathrm{M}) \mathrm{P}$ in contrasting soybean genotypes. Arrows denote the protein spots zoomed for better visualization. Bars in the graph denote the mean $(n=3)$ normalized intensity of protein spots on gels of EC-232019 Sufficient P (orange, SP ER), EC-232019 Low P (red, LP ER), EC-113396 Sufficient P (violet, SP IENR) and EC-113396 Low P (green, LP IENR). Proteins with significant Mascot score are presented here. Refer Table 1 for entire list of increased proteins. 

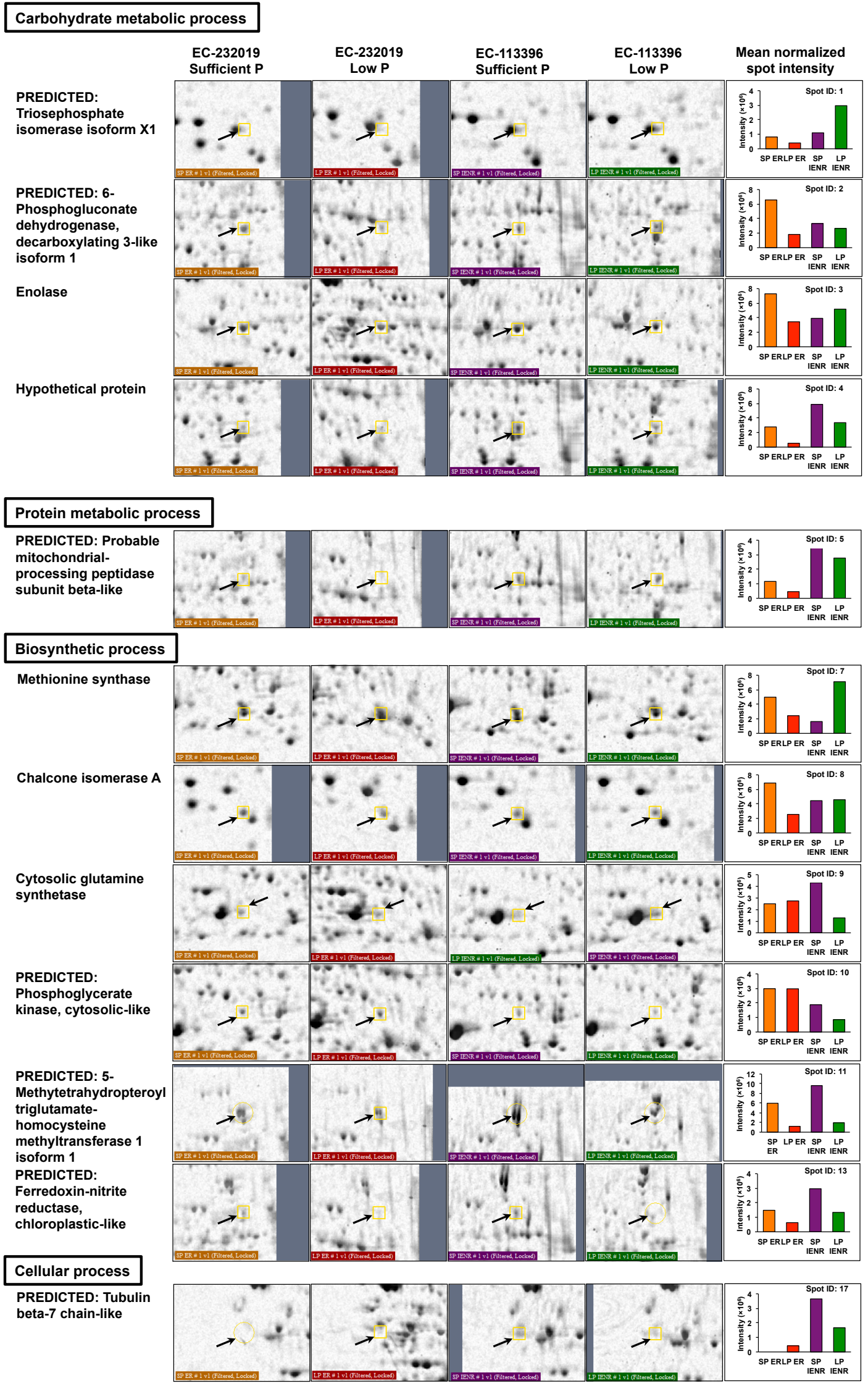

Figure 5. Cont. 


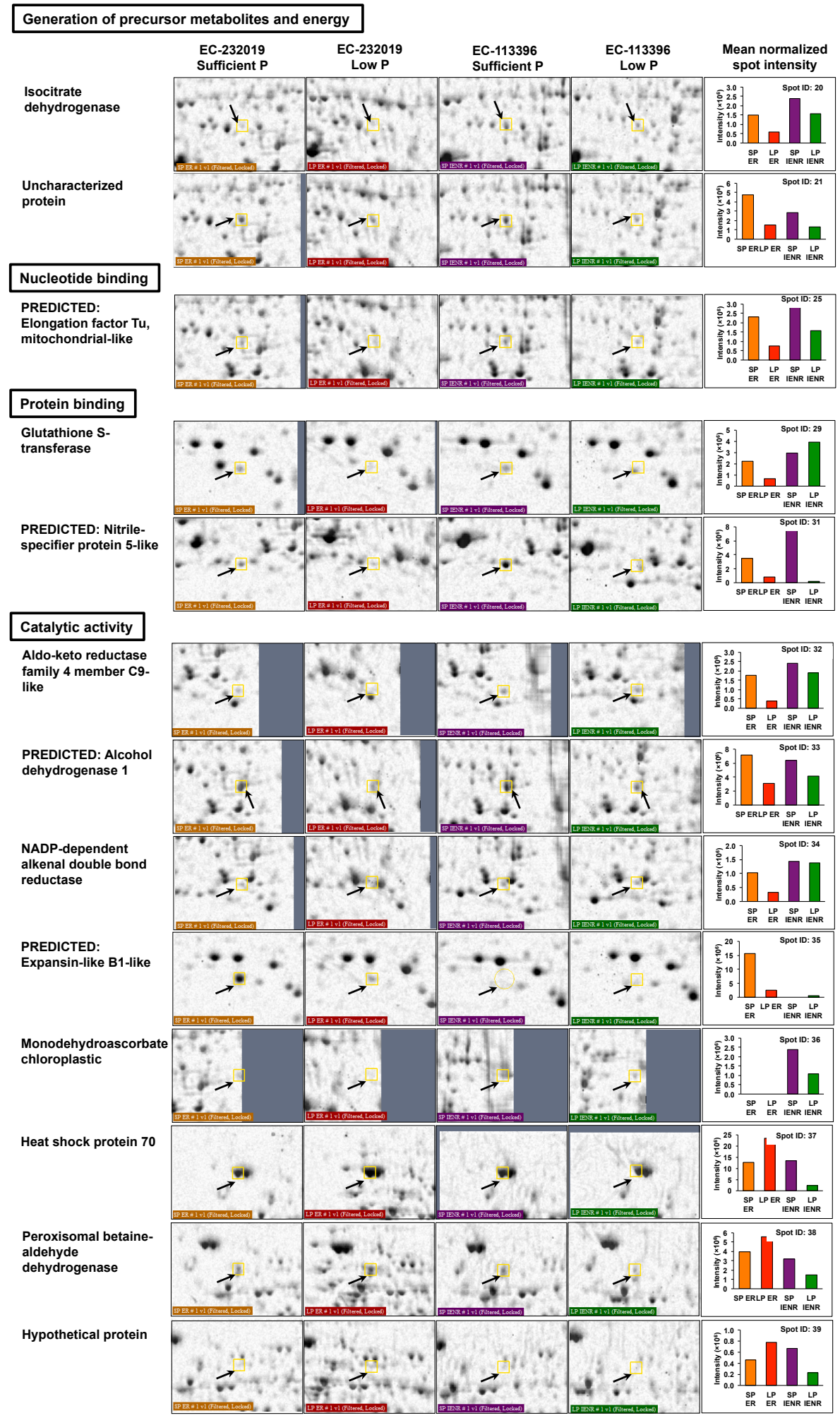

Figure 5. Root proteins decreased by more than two-fold at low $(4 \mu \mathrm{M}) \mathrm{P}$ in contrasting soybean genotypes. Arrows denote the protein spots zoomed for better visualization. Bars in the graph denote the mean $(n=3)$ normalized intensity of protein spots on gels ofEC-232019 Sufficient P (orange, SP ER), EC-232019 Low P (red, LP ER), EC-113396 Sufficient P (violet, SP IENR) and EC-113396 Low P (green, LP IENR). Proteins with significant Mascot score are presented here. Refer Table 2 for entire list of decreased proteins. 


\subsubsection{Validation of Expression of Genes Encoding DAPs in Response to Low P Stress}

To validate the expression levels of genes encoding DAPs, RT-qPCR was performed on 44 out of the 105 proteins that showed differential expression under low P stress. In EC-232019, the genes encoding isoflavone reductase, actin-7-like, malate dehydrogenase and monodehydroascorbate reductase were up-regulated by more than two-fold at low P compared to sufficient P (Figure 6A, Table S3A). Transcripts of phosphoglucomutase, phosphoglycerate mutase, heat shock cognate protein 80-like, trypsin inhibitor, cysteine synthase and an uncharacterized protein showed more than two-fold expression at low P in EC-113396. The gene encoding ATP synthase $\beta$ subunit was up-regulated by more than two-fold in both the genotypes. Contrary to protein expression, transcripts of the genes encoding fructokinase and cytosolic glutamine synthetase $\beta_{2}$ were down-regulated at low P compared to sufficient $\mathrm{P}$ in both genotypes. Similarly, 19 genes were down-regulated at low $\mathrm{P}$ compared to sufficient $\mathrm{P}$ in agreement with protein expression pattern, whereas contrary to the proteome profile, transcripts of the genes encoding methionine synthase and glutathione S-transferase were up-regulated at low P compared to sufficient P in EC-232019 (Figure 6B, Table S3B). In summary, 36 genes displayed trends at the transcript level that were consistent with protein expression, while eight genes exhibited transcription trends that were opposite to that observed in the proteome profile.

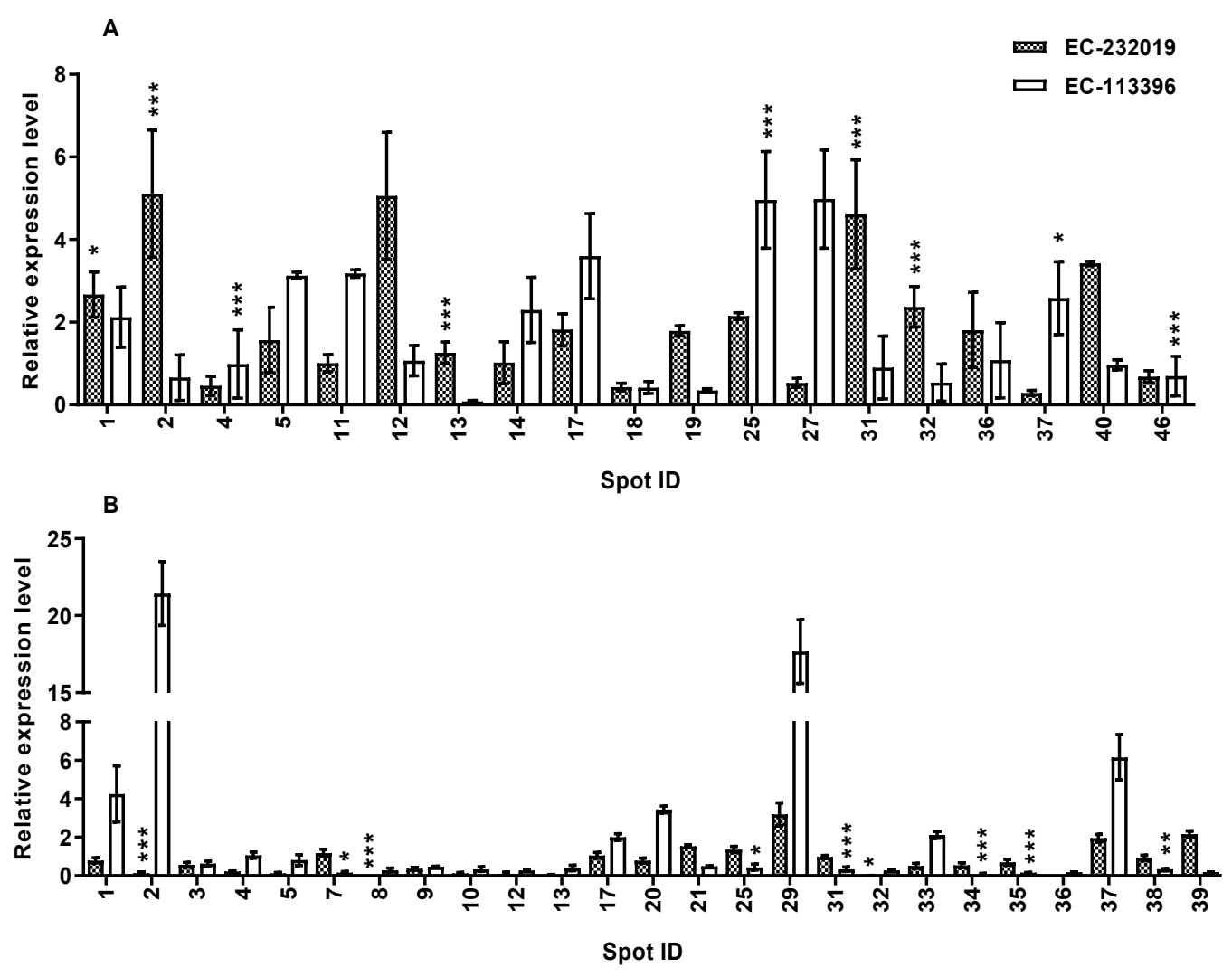

Figure 6. Relative transcript levels of genes encoding differentially abundant proteins (A) up-regulated and (B) down-regulated by more than two-fold at low $(4 \mu \mathrm{M}) \mathrm{P}$ in soybean roots. Data correspond to mean \pm SE $(n=9)$. Spot ID corresponds to the protein spots in Supplemental Figure S3B,D. * ${ }^{* *}$ and *** denote significance at $0.05,0.01$ and 0.001 probability levels, respectively. 
Table 1. Root proteins increased by more than two-fold at low $(4 \mu \mathrm{M})$ phosphorus $(\mathrm{P})$ in contrasting soybean genotypes.

\begin{tabular}{|c|c|c|c|c|c|c|c|c|c|}
\hline Spot ID & Accession Number & Description & Taxonomic Database & E & $\mathrm{M}_{\mathrm{r}}(\mathrm{kDa})$ & pI & Mascot Score & $\# \mathbf{P}$ & $\mathrm{C}(\%)$ \\
\hline \multicolumn{10}{|c|}{ Carbohydrate metabolic process } \\
\hline $1^{\mathrm{a}}$ & XP_003534616.1 & $\begin{array}{l}\text { Predicted: 2,3-Bisphosphoglycerate-independent } \\
\text { phosphoglycerate mutase-like }\end{array}$ & Glycine max & 0.00013 & 61.1 & 5.51 & 106 & $10 / 10$ & 31 \\
\hline $2^{\mathrm{a}}$ & NP_001243291.1 & Malate dehydrogenase, cytoplasmic-like & Glycine $\max$ & 0.00017 & 35.5 & 5.91 & 105 & $8 / 12$ & 38 \\
\hline $3^{\mathrm{a}}$ & XP_018674024.1 & Predicted: $\alpha$-glucan water dikinase 2 isoform X2 & Musa acuminata subsp. malaccensis & 0.44 & 144.4 & 8.55 & 71 & $10 / 10$ & 8 \\
\hline $4^{\mathrm{b}}$ & XP_003537935.1 & Predicted: Fructokinase-2-like & Glycine $\max$ & $5.3 \times 10^{-12}$ & 35.6 & 4.96 & 180 & $12 / 8$ & 47 \\
\hline $5^{\mathrm{b}}$ & XP_003552336.1 & $\begin{array}{c}\text { Predicted: 2,3-bisphosphoglycerate-independent } \\
\text { phosphoglycerate mutase }\end{array}$ & Glycine max & $2.6 \times 10^{-5}$ & 61.1 & 5.58 & 113 & $10 / 10$ & 25 \\
\hline $6^{\mathrm{b}}$ & BAS92721.1 & Predicted protein & Oryza sativa Japonica & 0.17 & 14.1 & 10.27 & 75 & $5 / 15$ & 34 \\
\hline $7^{\mathrm{b}}$ & XP_001758882.1 & Predicted: $\beta$-galactosyltransferase 7-like & Physcomitrella patens & 0.44 & 45.1 & 8.25 & 71 & $6 / 9$ & 16 \\
\hline $8^{\mathrm{b}}$ & XP_003531483.1 & Phosphoglycerate kinase isomerase, cytosolic & Glycine max & 6.6 & 42.4 & 6.28 & 59 & $5 / 15$ & 18 \\
\hline $9^{\mathrm{b}}$ & XP_021745158.1 & SW15-dependent HO expression protein 3-like & Chenopodium quinoa & 3.0 & 21.2 & 10.00 & 62 & $6 / 14$ & 28 \\
\hline $10^{\mathrm{b}}$ & XP_019436544.1 & Predicted: Fructokinase-2-like & Lupinus angustifolius & 5.4 & 35.8 & 5.28 & 60 & $6 / 14$ & 25 \\
\hline $11^{\mathrm{a}, \mathrm{b}}$ & XP_006580435.1 & Predicted: Phosphoglucomutase, cytoplasmic-like & Glycine max & $2.1 \times 10^{-5}$ & 63.7 & 5.33 & 114 & $11 / 9$ & 20 \\
\hline \multicolumn{10}{|c|}{ Protein metabolic process } \\
\hline $12^{\mathrm{a}}$ & XP_003525105.1 & Predicted: Actin-7-like & Glycine max & $5.3 \times 10^{-6}$ & 41.9 & 5.37 & 120 & $10 / 10$ & 38 \\
\hline $13^{\mathrm{a}}$ & KHN39675.1 & Stromal $70 \mathrm{kDa}$ heat shock-related protein, chloroplastic & Glycine soja & 0.0021 & 65.5 & 4.84 & 94 & $10 / 10$ & 21 \\
\hline $14^{\mathrm{a}}$ & XP_010063241.1 & Predicted: Heat shock cognate protein 80 -like & Eucalyptus grandis & 0.016 & 80.8 & 4.94 & 85 & 9/11 & 11 \\
\hline $15^{\mathrm{a}}$ & XP_006422243.1 & Hypothetical: Proteasome subunit $\alpha$ type-2-a & Citrus clementia & 0.12 & 21.6 & 7.88 & 76 & $6 / 14$ & 31 \\
\hline $16^{\mathrm{a}}$ & CDY43475.1 & Predicted protein & Brassica napus & 21.0 & 6.2 & 4.78 & 54 & $4 / 16$ & 38 \\
\hline $17^{\mathrm{b}}$ & XP_015954976.1 & Proteasome subunit $\beta$ type-2-b & Arachis duranensis & $1.7 \times 10^{-5}$ & 22.7 & 6.30 & 115 & $7 / 13$ & 37 \\
\hline \multicolumn{10}{|c|}{ Biosynthetic process } \\
\hline $18^{\mathrm{a}}$ & NP_001242332.2 & Glutamine synthetase $\beta_{2}$, cytosolic & Glycine max & $6.6 \times 10^{-6}$ & 39.3 & 5.48 & 119 & $9 / 11$ & 40 \\
\hline $19^{a}$ & XP_003555932.1 & Predicted: ATP synthase subunit $\beta$, mitochondrial-like & Glycine max & 0.00011 & 59.9 & 5.80 & 107 & $10 / 10$ & 26 \\
\hline $20^{a}$ & XP_014514203.1 & ATP synthase subunit, mitochondrial & Vigna radiata var. radiata & 0.12 & 59.8 & 5.90 & 76 & $8 / 12$ & 19 \\
\hline $21^{a}$ & XP_009122013.1 & Argininosuccinate lyase & Brassica rapa & 0.17 & 58.3 & 5.41 & 75 & $8 / 12$ & 18 \\
\hline $22^{\mathrm{a}}$ & AQK43314.1 & Hypothetical: Nucleoside diphosphate kinase 1 & Glycine max & 0.11 & 44.0 & 9.56 & 77 & $8 / 12$ & 20 \\
\hline $23^{\mathrm{a}}$ & KHN48251.1 & Adenosine kinase 2 & Glycine soja & 0.33 & 38.1 & 5.29 & 72 & $6 / 14$ & 29 \\
\hline $24^{\mathrm{a}}$ & XP_009394624.1 & Uncharacterized protein & Musa acuminata subsp. malaccensis & 1.1 & 64.9 & 9.87 & 67 & $8 / 12$ & 16 \\
\hline $25^{\mathrm{b}}$ & XP_003536650.1 & Predicted: ATP synthase subunit $\beta$, mitochondrial & Glycine $\max$ & $5.3 \times 10^{-11}$ & 59.9 & 5.80 & 170 & $14 / 6$ & 38 \\
\hline $26^{\mathrm{b}}$ & KZM83344.1 & Hypothetical protein & Daucus carota subsp. sativus & 0.33 & 14.2 & 6.41 & 72 & $5 / 15$ & 44 \\
\hline $27^{\mathrm{a}, \mathrm{b}}$ & KHN32353.1 & Cysteine synthase, chloroplastic/chromoplastic & Glycine soja & 0.014 & 37.3 & 5.67 & 86 & $7 / 13$ & 27 \\
\hline $28^{a, b}$ & XP_020889182.1 & Glutamine synthetase cytosolic isozyme 1-3-like & Arabidopsis lyrata subsp. lyrata & 0.16 & 38.7 & 5.72 & 75 & $7 / 13$ & 18 \\
\hline \multicolumn{10}{|c|}{ Lipid metabolic process } \\
\hline $29^{a, b}$ & CDY19393.1 & Hypothetical: Oxysterol-binding protein 1d & Brassica napus & 0.34 & 88.7 & 6.07 & 72 & $9 / 11$ & 11 \\
\hline $30^{\mathrm{a}, \mathrm{b}}$ & KXG23463.1 & $\begin{array}{l}\text { Hypothetical: 3-hydroxy-3-methylglutaryl-coenzyme a } \\
\text { reductase 1-like }\end{array}$ & Sorghum bicolor & $2 \mathrm{e}^{+2}$ & 9.8 & 5.88 & 44 & $3 / 9$ & 24 \\
\hline
\end{tabular}


Table 1. Cont

\begin{tabular}{|c|c|c|c|c|c|c|c|c|c|}
\hline Spot ID & Accession Number & Description & Taxonomic Database & E & $\mathrm{M}_{\mathrm{r}}(\mathrm{kDa})$ & pI & Mascot Score & \#P & C (\%) \\
\hline \multicolumn{10}{|c|}{ Cellular homeostasis } \\
\hline $31^{\mathrm{a}}$ & NP_001236037.2 & Isoflavone reductase & Glycine max & $1.7 \times 10^{-11}$ & 35.7 & 5.30 & 175 & $11 / 9$ & 47 \\
\hline $32^{\mathrm{a}}$ & XP_003557022.1 & Predicted: Monodehydroascorbate reductase & Glycine max & 0.057 & 47.1 & 5.49 & 80 & $7 / 13$ & 21 \\
\hline \multicolumn{10}{|c|}{ Nucleobase-containing compound metabolic process } \\
\hline $33^{\mathrm{a}}$ & XP_010932834.1 & Predicted: ATP sulfurylase 1, chloroplastic-like & Elaeis guineensis & 23.0 & 53.8 & 9.36 & 54 & $6 / 9$ & 8 \\
\hline \multicolumn{10}{|c|}{ Cellular process } \\
\hline $34^{\mathrm{a}}$ & KRH58847.1 & Predicted: S-adenosyl-homocysteinase hydrolase & Glycine max & 0.13 & 55.7 & 5.79 & 76 & $8 / 12$ & 21 \\
\hline $35^{\mathrm{a}}$ & KOM56630.1 & $\begin{array}{l}\text { Hypothetical: Mediator of RNA polymerase II } \\
\text { transcription subunit } 32\end{array}$ & Vigna angularis & 1.1 & 61.9 & 11.06 & 67 & $8 / 12$ & 16 \\
\hline $36^{\mathrm{a}, \mathrm{b}}$ & XP_011039269.1 & Predicted: Tubulin beta chain-like & Populus euphratica & 0.0019 & 50.7 & 4.76 & 94 & $8 / 12$ & 18 \\
\hline $37^{\mathrm{a}, \mathrm{b}}$ & NP_001237543.1 & Trypsin inhibitor & Glycine max & 0.0047 & 18.3 & 6.12 & 90 & $6 / 14$ & 53 \\
\hline $38^{\mathrm{a}, \mathrm{b}}$ & OMO89133.1 & Shoot gravitropism protein & Corchorus capsularis & 0.34 & 105.8 & 5.32 & 72 & $10 / 10$ & 9 \\
\hline \multicolumn{10}{|c|}{ Generation of precursor metabolites and energy } \\
\hline $39^{\mathrm{a}, \mathrm{b}}$ & AGV54452.1 & NADPH-specific isocitrate dehydrogenase & Phaseolus vulgaris & 1.3 & 46.4 & 6.00 & 66 & $8 / 12$ & 17 \\
\hline \multicolumn{10}{|c|}{ Signal transduction } \\
\hline $40^{\mathrm{a}}$ & OTG28653.1 & Hypothetical protein & Helianthus annuus & 0.028 & 91.3 & 5.20 & 83 & 9/11 & 12 \\
\hline $41^{\mathrm{a}, \mathrm{b}}$ & XP_002959041.1 & Small ARF-related GTPase & Volvox carterif. nagariensis & $1.6 \mathrm{e}^{+2}$ & 20.1 & 6.74 & 45 & $4 / 16$ & 30 \\
\hline \multicolumn{10}{|c|}{ Nucleic acid/protein binding } \\
\hline $42^{b}$ & OWM88181.1 & Hypothetical protein & Punica granatum & 3.3 & 57.5 & 9.61 & 62 & $7 / 13$ & 17 \\
\hline $43^{\mathrm{a}, \mathrm{b}}$ & GAU40109.1 & Hypothetical protein & Trifolium subterraneum & 0.46 & 53.1 & 6.19 & 71 & $7 / 13$ & 14 \\
\hline $44^{\mathrm{a}, \mathrm{b}}$ & XP_019085342.1 & Uncharacterized protein & Camelina sativa & 0.48 & 101.2 & 9.42 & 70 & $7 / 13$ & 7 \\
\hline \multicolumn{10}{|c|}{ Translation } \\
\hline $45^{\mathrm{a}, \mathrm{b}}$ & AAY62839.1 & Small ribosomal protein subunit 4, partial & Haplohymenium triste & 0.092 & 22.3 & 10.17 & 78 & $6 / 14$ & 33 \\
\hline \multicolumn{10}{|c|}{ Transport } \\
\hline $46^{\mathrm{a}, \mathrm{b}}$ & KHN32468.1 & Patellin-5 & Glycine soja & 0.024 & 35.2 & 8.73 & 84 & $7 / 13$ & 18 \\
\hline \multicolumn{10}{|c|}{ Transferase activity } \\
\hline $47^{\mathrm{b}}$ & OIW11558.1 & Hypothetical: Methyltransferase & Lupinus angustifolius & 5.9 & 76.6 & 4.93 & 60 & $8 / 12$ & 11 \\
\hline
\end{tabular}


Table 1. Cont.

\begin{tabular}{|c|c|c|c|c|c|c|c|c|c|}
\hline Spot ID & Accession Number & Description & Taxonomic Database & E & $\mathrm{M}_{\mathrm{r}}(\mathrm{kDa})$ & pI & Mascot Score & $\# \mathbf{P}$ & $\mathrm{C}(\%)$ \\
\hline \multicolumn{10}{|c|}{ Unknown } \\
\hline $48^{\mathrm{a}}$ & XP_003064461.1 & Predicted protein & Micromonas pusilla & 0.11 & 46.7 & 9.84 & 77 & $8 / 12$ & 19 \\
\hline $49^{a}$ & KDP45225.1 & Hypothetical protein & Jatropha curcas & 0.32 & 27.0 & 5.33 & 72 & $6 / 14$ & 27 \\
\hline $50^{a}$ & XP_002953155.1 & Hypothetical protein & Volvox carterif. nagariensis & 0.28 & 44.4 & 6.96 & 71 & $7 / 13$ & 14 \\
\hline $51^{a}$ & OWM69200.1 & Hypothetical protein & Punica granatum & 3.1 & 76.6 & 7.72 & 62 & $6 / 11$ & 8 \\
\hline $52^{a}$ & BAD15857.1 & Hypothetical protein & Oryza sativa Japonica & $5.2 \mathrm{e}^{+2}$ & 14.7 & 12.21 & 40 & $4 / 16$ & 31 \\
\hline $53^{\mathrm{a}}$ & XP_020159678.1 & $\begin{array}{c}\text { Predicted: Vacuolar-sorting receptor } \\
\text { 1-like isoform X3 }\end{array}$ & Aegilopos tauschii subsp. Tauschii & $1.7 \mathrm{e}^{+3}$ & 25.5 & 5.57 & 35 & $3 / 14$ & 8 \\
\hline $54^{\mathrm{b}}$ & OAE31941.1 & Hypothetical protein & $\begin{array}{l}\text { Marchantia polymorpha } \\
\text { subsp. ruderalis }\end{array}$ & 0.34 & 18.0 & 7.90 & 72 & $6 / 14$ & 25 \\
\hline $55^{\mathrm{b}}$ & XP_017621778.1 & Uncharacterized protein & Gossypium arboreum & 0.31 & 18.1 & 11.28 & 72 & $6 / 14$ & 39 \\
\hline $56^{\mathrm{b}}$ & XP_018726619.1 & Predicted: Disease resistance protein & Eucalyptus grandis & 6.2 & 33.1 & 7.01 & 59 & $6 / 14$ & 17 \\
\hline $57^{\mathrm{b}}$ & XP_020253187.1 & $\mathrm{R} 3 \mathrm{H}$ and coiled-coil domain-containing protein & Asparagus officinalis & 6.3 & 39.1 & 4.78 & 59 & $6 / 14$ & 18 \\
\hline $58^{\mathrm{a}, \mathrm{b}}$ & XP_018450448.1 & Lysine-specific demethylase & Raphanus sativus & 7.4 & 99.2 & 6.12 & 58 & $6 / 14$ & 7 \\
\hline $59^{\mathrm{a}, \mathrm{b}}$ & EPS63431.1 & $\begin{array}{c}\text { Hypothetical: Probable membrane-associated } \\
\text { kinase regulator } 1\end{array}$ & Genlisea aurea & 25.0 & 23.9 & 10.24 & 53 & $5 / 15$ & 26 \\
\hline $60^{\mathrm{a}, \mathrm{b}}$ & KHG04359.1 & Hypothetical protein & Gossypium arboreum & 3.6 & 3.4 & 3.87 & 62 & $3 / 17$ & 90 \\
\hline $61^{\mathrm{a}, \mathrm{b}}$ & XP_011087585.1 & Uncharacterized protein & Sesamum indicum & $2.1 \mathrm{e}^{+2}$ & 43.8 & 4.77 & 44 & $5 / 15$ & 8 \\
\hline
\end{tabular}

Spot ID corresponds to the protein spots in Supplemental Figure S3B,D. Superscripts ${ }^{\mathrm{a}}$ and ${ }^{\mathrm{b}}$ denote increased proteins at low P compared to sufficient $\mathrm{P}$ in EC-232019 and EC-113396, respectively. E denotes the expectation value, $\mathrm{M}_{\mathrm{r}}$ and $\mathrm{pI}$ are monoisotopic mass and calculated isoelectric point, respectively. \#P and $\mathrm{C}$ denote the number of matched/unmatched peptides and protein sequence coverage, respectively. Proteins with Mascot score $>80$ are significant $(P<0.05)$ 
Table 2. Root proteins decreased by more than two-fold at low $(4 \mu \mathrm{M}) \mathrm{P}$ in contrasting soybean genotypes.

\begin{tabular}{|c|c|c|c|c|c|c|c|c|c|}
\hline Spot ID & Accession Number & Description & Taxonomic Database & $\mathrm{E}$ & $\mathrm{M}_{\mathrm{r}}(\mathrm{kDa})$ & pI & Mascot Score & $\# \mathbf{P}$ & $\mathrm{C}(\%)$ \\
\hline \multicolumn{10}{|c|}{ Carbohydrate metabolic process } \\
\hline $1^{\mathrm{a}}$ & XP_003547334.1 & \multirow{4}{*}{$\begin{array}{c}\text { Predicted: Triosephosphate isomerase isoform X1 } \\
\text { Predicted: 6-Phosphogluconate dehydrogenase, } \\
\text { decarboxylating 3-like isoform } 1 \\
\text { Enolase } \\
\text { Hypothetical protein }\end{array}$} & Glycine max & $5.3 \times 10^{-6}$ & 27.4 & 5.87 & 120 & 9/11 & 36 \\
\hline $2^{\mathrm{a}}$ & XP_003531895.1 & & Glycine max & $5.3 \times 10^{-6}$ & 53.8 & 6.11 & 120 & $11 / 9$ & 31 \\
\hline $3^{\mathrm{a}}$ & AAS18240.1 & & Glycine max & 0.017 & 48.0 & 5.31 & 85 & 9/11 & 23 \\
\hline $4^{\mathrm{a}}$ & OQU84669.1 & & Sorghum bicolor & 0.028 & 4.0 & 10.04 & 83 & $4 / 16$ & 94 \\
\hline \multicolumn{10}{|c|}{ Protein metabolic process } \\
\hline $5^{\mathrm{a}}$ & XP_003552094.1 & $\begin{array}{l}\text { Predicted: Probable mitochondrial-processing peptidase } \\
\text { subunit } \beta \text {-like }\end{array}$ & Glycine max & $1.1 \times 10^{-7}$ & 58.8 & 6.49 & 137 & $12 / 8$ & 27 \\
\hline $6^{\mathrm{a}}$ & OMO96428.1 & Hypothetical protein & Glycine max & 0.24 & 85.7 & 5.22 & 73 & $9 / 11$ & 11 \\
\hline \multicolumn{10}{|c|}{ Biosynthetic process } \\
\hline $7^{\mathrm{a}}$ & NP_001235794.1 & Methionine synthase & Glycine max & $3.3 \times 10^{-11}$ & 84.4 & 5.93 & 172 & $15 / 5$ & 25 \\
\hline $8^{\mathrm{a}}$ & NP_001235219.1 & Chalcone isomerase $\mathrm{A}$ & Glycine max & 0.0046 & 23.3 & 6.23 & 91 & $7 / 13$ & 41 \\
\hline $9^{\mathrm{b}}$ & NP_001238531.2 & Cytosolic glutamine synthetase & Glycine max & $4.2 \times 10^{-5}$ & 39.1 & 5.48 & 111 & $9 / 11$ & 31 \\
\hline $10^{\mathrm{b}}$ & XP_003546821.1 & Predicted: Phosphoglycerate kinase, cytosolic-like & Glycine max & 0.00074 & 42.4 & 5.48 & 98 & $9 / 11$ & 28 \\
\hline $11^{\mathrm{b}}$ & XP_016685735.1 & $\begin{array}{l}\text { L10-interacting MYB domain-containing } \\
\text { protein-like, isoform X1 } \\
\text { Predicted: }\end{array}$ & Gossypium hirsutum & 0.14 & 36.0 & 5.96 & 76 & $7 / 13$ & 20 \\
\hline $12^{\mathrm{a}, \mathrm{b}}$ & XP_003554033.1 & $\begin{array}{l}\text { 5-Methytetrahydropteroyltriglutamate-homocysteine } \\
\text { methyltransferase } 1 \text { isoform } 1\end{array}$ & Glycine max & $4.2 \times 10^{-6}$ & 84.4 & 8.73 & 121 & $12 / 8$ & 23 \\
\hline $13^{\mathrm{a}, \mathrm{b}}$ & XP_003529397.1 & Predicted: Ferredoxin-nitrite reductase, chloroplastic-like & Glycine max & 0.036 & 66.5 & 5.97 & 82 & $9 / 11$ & 14 \\
\hline $14^{\mathrm{a}, \mathrm{b}}$ & XP_016752752.1 & Uncharacterized: ATP synthase $\mathrm{CF}_{0}$ subunit I & Gossypium hirsutum & 0.29 & 26.4 & 6.31 & 73 & $7 / 13$ & 21 \\
\hline \multicolumn{10}{|c|}{ Nucleobase-containing compound metabolic process } \\
\hline $15^{\mathrm{a}}$ & Gm_SSP8106 ${ }^{\mathrm{a}}$ & Predicted protein & Ostreococcus lucimarinus & 0.28 & 46.3 & 6.30 & 73 & $6 / 9$ & 19 \\
\hline $16^{\mathrm{a}, \mathrm{b}}$ & XP_021735866.1 & Uncharacterized: ATP sulfurylase 2 & Chenopodium quinoa & 2.6 & 92.0 & 5.49 & 63 & $7 / 13$ & 8 \\
\hline \multicolumn{10}{|c|}{ Cellular process } \\
\hline $17^{\mathrm{b}}$ & XP_009141007.1 & Predicted: Tubulin $\beta-7$ chain-like & Brassica napus & 0.00017 & 51.2 & 4.73 & 105 & $9 / 11$ & 22 \\
\hline $18^{\mathrm{b}}$ & XP_016580376.1 & Sulfite oxidase & Capsicum аппиит & 3.0 & 69.1 & 9.45 & 62 & $6 / 14$ & 11 \\
\hline $19^{\mathrm{b}}$ & OQU86022.1 & Hypothetical: Kinesin heavy chain & Sorghum bicolor & 3.5 & 14.6 & 9.35 & 62 & $5 / 15$ & 48 \\
\hline \multicolumn{10}{|c|}{ Generation of precursor metabolites and energy } \\
\hline $20^{\mathrm{a}}$ & AAA33978.1 & Isocitrate dehydrogenase & Glycine max & $5.3 \times 10^{-9}$ & 49.5 & 6.13 & 150 & $13 / 7$ & 32 \\
\hline $21^{\mathrm{a}, \mathrm{b}}$ & NP_001241237.1 & Uncharacterized protein & Glycine max & $6.6 \times 10^{-9}$ & 46.4 & 5.87 & 149 & $13 / 7$ & 32 \\
\hline \multicolumn{10}{|c|}{ Metabolic process } \\
\hline $22^{\mathrm{a}}$ & XP_013467839.1 & Pyridoxal-5'-phosphate-dependent enzyme family protein & Medicago truncatula & 0.21 & 22.2 & 7.66 & 74 & $6 / 14$ & 30 \\
\hline \multicolumn{10}{|c|}{ Signal transduction } \\
\hline $23^{\mathrm{a}}$ & XP_006584765.1 & Predicted: Calcineurin B-like protein 2-like & Glycine max & 4.0 & 23.9 & 4.84 & 61 & $5 / 15$ & 22 \\
\hline
\end{tabular}


Table 2. Cont.

\begin{tabular}{|c|c|c|c|c|c|c|c|c|c|}
\hline Spot ID & Accession Number & Description & Taxonomic Database & $\mathrm{E}$ & $\mathrm{M}_{\mathrm{r}}(\mathrm{kDa})$ & pI & Mascot Score & $\# \mathbf{P}$ & $\mathrm{C}(\%)$ \\
\hline \multicolumn{10}{|c|}{ Nucleotide/Nucleic acid binding } \\
\hline $24^{\mathrm{a}}$ & XP_009797404.1 & Predicted: Glycine-rich RNA-binding protein 4 & Nicotiana sylvestris & 1.3 & 18.4 & 9.32 & 66 & $5 / 15$ & 31 \\
\hline $25^{\mathrm{a}}$ & NP_001276267.2 & Predicted: Elongation factor $\mathrm{Tu}$, mitochondrial-like & Glycine max & 0.05 & 49.3 & 6.40 & 80 & $8 / 12$ & 23 \\
\hline $26^{\mathrm{b}}$ & XP_016674018.1 & $\begin{array}{l}\text { Predicted: Coiled-coil domain-containing protein } 22 \\
\text { homolog isoform X2 }\end{array}$ & Gossypium hirsutum & $2 \mathrm{e}^{+2}$ & 56.1 & 4.93 & 44 & $5 / 8$ & 8 \\
\hline \multicolumn{10}{|c|}{ Transport } \\
\hline $27^{\mathrm{a}}$ & XP_007509415.1 & Unknown protein & Bathycoccus prasinos & 0.86 & 84.2 & 5.04 & 68 & $7 / 13$ & 10 \\
\hline $28^{\mathrm{a}}$ & XP_021753870.1 & Uncharacterized: ATP synthase $\mathrm{CF}_{1} \alpha$ & Chenopodium quinoa & 0.18 & 20.2 & 8.91 & 75 & $5 / 7$ & 19 \\
\hline \multicolumn{10}{|c|}{ Protein binding } \\
\hline $29^{\mathrm{a}}$ & NP_001239642.1 & Glutathione S-transferase & Glycine $\max$ & $3.3 \times 10^{-5}$ & 24.9 & 5.73 & 112 & $7 / 13$ & 36 \\
\hline $30^{\mathrm{a}}$ & XP_021316845.1 & Acyl-binding domain-containing protein 5-like & Sorghum bicolor & 0.19 & 77.1 & 8.85 & 74 & $9 / 11$ & 19 \\
\hline $31^{\mathrm{a}, \mathrm{b}}$ & XP_003531506.1 & Predicted: Nitrile-specifier protein 5-like & Glycine max & $3.3 \times 10^{-15}$ & 36.0 & 5.59 & 212 & $14 / 6$ & 55 \\
\hline \multicolumn{10}{|c|}{ Catalytic activity } \\
\hline $32^{\mathrm{a}}$ & KHN43834.1 & Aldo-keto reductase family 4 member C9-like & Glycine max & $1.3 \times 10^{-9}$ & 35.0 & 6.40 & 156 & $12 / 8$ & 47 \\
\hline $33^{\mathrm{a}}$ & NP_001340170.1 & Predicted: Alcohol dehydrogenase 1 & Glycine max & $2.6 \times 10^{-5}$ & 41.6 & 5.97 & 113 & $9 / 11$ & 32 \\
\hline $34^{\mathrm{a}}$ & KHN30856.1 & NADP-dependent alkenal double bond reductase & Glycine max & 0.036 & 38.0 & 5.94 & 82 & $7 / 13$ & 25 \\
\hline $35^{\mathrm{a}}$ & XP_003549946.1 & $\begin{array}{l}\text { Predicted: Expansin-like B1-like } \\
\text { Preding }\end{array}$ & Glycine max & 0.00021 & 28.2 & 6.30 & 104 & $7 / 13$ & 43 \\
\hline $36^{\mathrm{b}}$ & KHN16790.1 & Monodehydroascorbate chloroplastic & Glycine max & $2.1 \times 10^{-5}$ & 52.4 & 8.36 & 144 & $12 / 8$ & 33 \\
\hline $37^{\mathrm{b}}$ & XP_003521330.1 & Heat shock protein 70 & Glycine max & $6.6 \times 10^{-7}$ & 71.8 & 5.05 & 129 & $12 / 8$ & 26 \\
\hline $38^{\mathrm{b}}$ & NP_001234990.1 & Peroxisomal betaine-aldehyde dehydrogenase & Glycine max & 0.00021 & 55.4 & 5.23 & 104 & $10 / 10$ & 17 \\
\hline $39^{\mathrm{b}}$ & KCW74152.1 & Hypothetical protein & Eucalyptus grandis & 0.046 & 52.8 & 9.73 & 81 & $10 / 10$ & 18 \\
\hline \multicolumn{10}{|c|}{ Kinase activity } \\
\hline $40^{\mathrm{b}}$ & ONH93257.1 & Hypothetical: Serine threonine-protein kinase 19 & Prunus persica & 0.84 & 25.3 & 9.11 & 68 & $7 / 13$ & 25 \\
\hline \multicolumn{10}{|c|}{ Transferase activity } \\
\hline $41^{\mathrm{b}}$ & XP_004968119.1 & Predicted: o-linked n-acetylglucosamine transferase-like & Setaria italica & 0.11 & 50.3 & 10.45 & 77 & $8 / 12$ & 16 \\
\hline \multicolumn{10}{|c|}{ Unknown } \\
\hline $42^{\mathrm{a}}$ & XP_018476189.1 & Predicted: RRP12-like protein & Raphanus sativus & 0.44 & 141.5 & 8.88 & 71 & 9/11 & 11 \\
\hline $43^{\mathrm{a}}$ & XP_016506991.1 & Uncharacterized protein & Nicotiana tabacum & 0.45 & 17.4 & 8.95 & 71 & $6 / 14$ & 25 \\
\hline $44^{\mathrm{b}}$ & XP_011040448.1 & Uncharacterized protein & Populus euphratica & 2.1 & 83.8 & 6.22 & 64 & $7 / 7$ & 6 \\
\hline
\end{tabular}

Spot ID corresponds to the protein spots in Supplemental Figure S3A,C. Superscripts ${ }^{\mathrm{a}}$ and ${ }^{\mathrm{b}}$ denote decreased proteins at low P compared to sufficient P in EC-232019 and EC-113396, respectively. E denotes the expectation value, $\mathrm{M}_{\mathrm{r}}$ and $\mathrm{pI}$ are monoisotopic mass and calculated isoelectric point, respectively. \#P and $\mathrm{C}$ denote the number of matched/unmatched peptides and protein sequence coverage, respectively. Proteins with Mascot score $>80$ are significant $(P<0.05)$ 


\section{Discussion}

\subsection{Soybean Genotypes Exhibit Improved Root System Traitsand Carboxylate Efflux under Low P Stress}

Phosphorus nutrition had significant effect on the root system traits of both soybean genotypes, albeit the increase in root surface area and volume was augmented in the P-efficient EC-232019. Similar alterations to root morphology in response to low $\mathrm{P}$ stress was reported in lentil (Lens culinaris) [35], rapeseed [36], maize [37], green gram [10] and wheat [38]. P-efficient soybean genotype with improved root traits exhibited higher total P uptake under low P stress. The improved root system traits exhibited by the P-efficient soybean genotype EC-232019 attributed to the least reduction in total P uptake at low P compared to sufficient P. Higher root surface area improved $\mathrm{P}$ acquisition by increasing the amount of root exudates such as phosphatases, RNases, nucleases, apyrases and carboxylic acids [39]. Our results conform to responses of barley (Hordeum vulgare) to low P stress, wherein improved P uptake of efficient cultivars was attributed to enhanced root exudation that increased its ability to acquire more P [40]. P-efficient maize genotypes also exhibited higher carboxylic acid efflux, P uptake and biomass under low soil P availability in comparison to inefficient ones [41].

P-efficient soybean genotype EC-232019 exuded greater amounts of carboxylic acids under low $\mathrm{P}$ stress. Irrespective of $\mathrm{P}$ level or genotype, carboxylic acids in the root exudate comprised of fumarate $>$ oxalate $>$ lactate $>$ pyruvate $>$ succinate $>$ malate. Other workers reported root exudates comprising fumarate, citrate and malate in P-stressed alfalfa [6] and soybean [7], which supported our findings. Oxalate and malate were the major carboxylic acids detected in P-efficient soybean $[8,42]$. Carboxylates mobilize $\mathrm{P}$ bound to metal ligands in the soil, hence their functionality depends on the number and arrangement of carboxyl and hydroxyl moieties. The complexing capacity for $\mathrm{Al} / \mathrm{Fe} / \mathrm{Ca}$ follows the decreasing order of tri- $\left(\right.$ citrate $\left.^{3-}\right)>$ di- $\left(\right.$ malate $^{2-}$, oxalate $^{2-}$, fumarate fum $^{2-}$ succinate $\left.^{2}\right)>$ mono-carboxylic acids (lactate ${ }^{1-}$ ) [5]. Thus, soybean genotypes with higher root exudation potential efficiently maintain their tissue P status to sustain growth under low P stress condition.

\subsection{Soybean Genotypes Exhibit Differential Molecular Regulation under Low Posphorus Stress}

Results of comparative proteome analysis and validation by RT-qPCR have been consolidated in Figure 7, which illustrates the differential molecular regulation in soybean genotypes with contrasting carboxylic acid synthesis and efflux under low P stress; suggesting the crosstalk between various metabolic pathways implicated in conferring superior $\mathrm{P}$ acquisition efficiency under stress.

\subsubsection{Tricarboxylic Acid Cycle and Glycolysis}

Low P stress induced the expression of malate dehydrogenase in EC-232019 but not in EC-113396. Such a response at the molecular level might be attributed to increased synthesis and efflux of malate ions as observed in EC-232019 at low P. Further, abundance of isocitrate dehydrogenase decreased at low P (relative decline higher in EC-232019 compared to EC-113396), possibly leading to higher accumulation of malate in the root tissues [43]. 


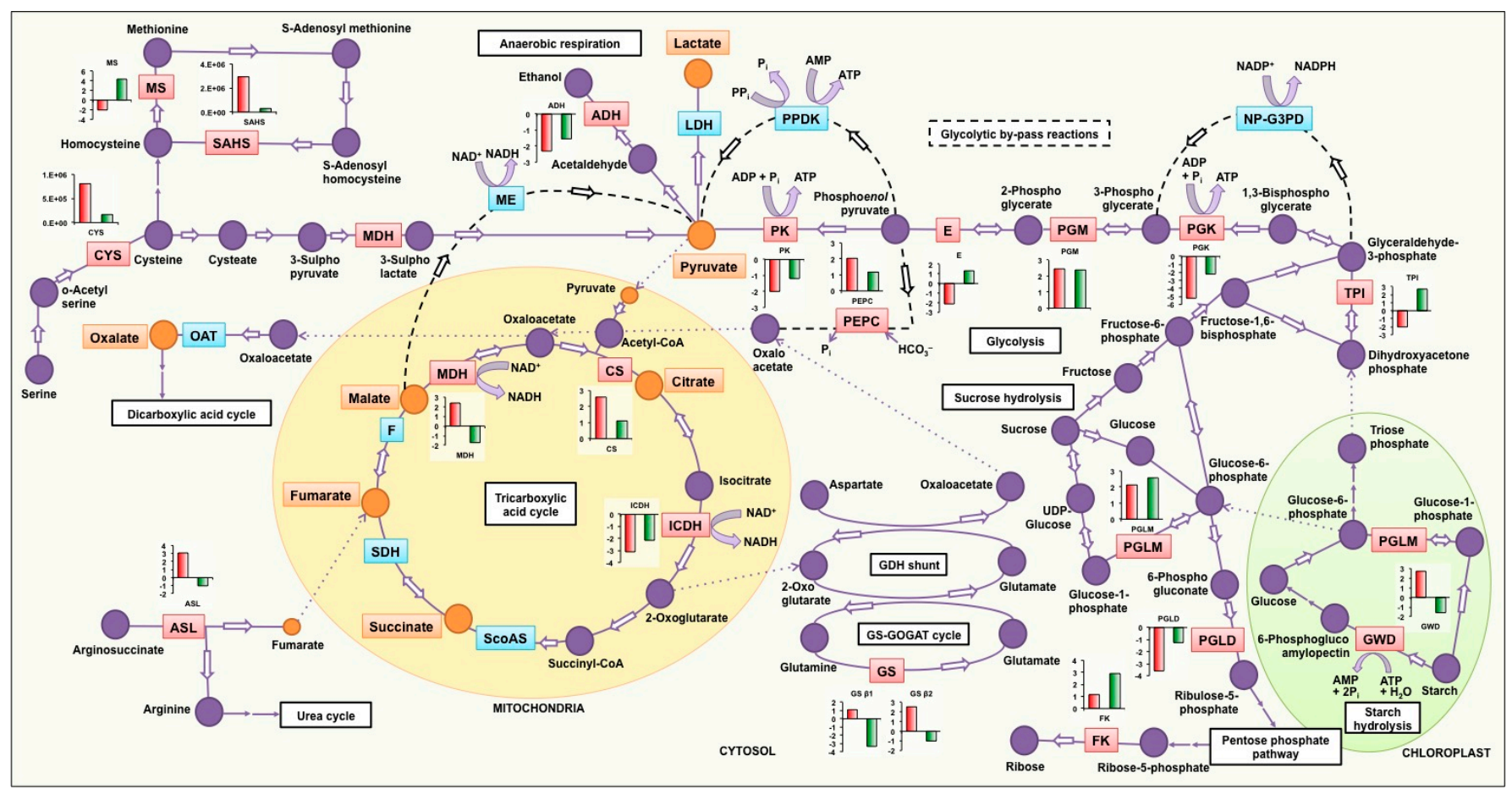

Figure 7. Model depicting involvement of several enzymes in carboxylic acid synthesis and glycolytic by-pass pathways functioning under low P stress in soybean roots. Carboxylic acids indicated in orange boxes were detected in the root exudates of soybean. Enzymes denoted in red boxes are differentially abundant under low P stress, relative fold change at low P compared to sufficient P in contrasting genotypes are denoted in red (EC-232019) and green (EC-113396) bars. Enzymes denoted in blue boxes might have a possible role in increasing carboxylic acid synthesis or glycolytic by-pass reactions under $\mathrm{P}$ stress. ADH: Alcohol dehydrogenase, ASL: Argininosuccinate lyase, CS: Citrate synthase, CYS: Cysteine synthase, E: Enolase, F: Fumarase, FK: Fructokinase, GDH: Glutamate dehydrogenase, GOGAT: Glutamate oxoglutarate amino transferase, GS: Glutamine synthetase, GWD: $\alpha$-glucan water dikinase, ICDH: Isocitrate dehydrogenase, LDH: Lactate dehydrogenase, MDH: Malate dehydrogenase, ME: Malic enzyme, MS: Methionine synthase, NP-G3PD: Non-phosphorylating NADP dependent glyceraldehyde-3-phosphate dehydrogenase, OAT: Oxaloacetase, PEPC: Phosphoenolpyruvate carboxylase, PGK: Phosphoglycerate kinase, PGLD: Phosphogluconate dehydrogenase, PGLM: Phosphoglucomutase, PGM: Phosphoglycerate mutase, PK: Pyruvate kinase, PPDK: Pyruvate phosphate dikinase, SAHS: S-adenosyl homocysteine synthase, ScoAS: Succinyl coenzyme A synthetase, SDH: Succinate dehydrogenase, TPI: Triosephosphate isomerase. PEPC, CS and PK data derived from enzyme activity (data published in Vengavasi et al. [26]). 
Citrate synthase activity was higher at low P in EC-232019 (data published in Vengavasi et al. [26]), which might have increased the synthesis of citrate required for induction of efflux in the efficient genotype. Similarly, increase in the activity of phosphoenolpyruvate carboxylase, one of the key regulatory enzymes for replenishment of carbon was higher in EC-232019 compared to EC-113396. Other enzymes in the glycolytic cycle including pyruvate kinase, enolase, phosphoglycerate kinase and triosephosphate isomerase decreased in EC-232019 under low P stress. Such a response in the P-efficient soybean genotype might indicate inorganic $\mathrm{P}$ recycling through alternative glycolytic by-pass reactions (dotted lines in Figure 7) catalyzed by nucleoside diphosphate kinase, non-phosphorylating NADP-glyceraldehyde-3-phosphate dehydrogenase, pyruvate phosphate dikinase, malic enzyme and phosphoenolpyruvate carboxylase [44]. In concurrence, abundance of nucleoside diphosphate kinase increased at low P in EC-232019.

\subsubsection{Starch Hydrolysis}

Glucan water dikinase, an important enzyme involved in starch hydrolysis was increased by low P stress in EC-232019 but not in EC-113396, thereby increasing the flux of carbon through glycolysis and tricarboxylic acid cycle (TCA) cycle.

\subsubsection{Anaerobic Respiration}

Alcohol dehydrogenase, the major enzyme producing ethanol from pyruvate decreased under low $\mathrm{P}$ stress in both genotypes, indicating the possible production of lactate ions, as evident from its higher efflux in soybean (Figure 2G).

\subsubsection{Other Anaplerotic Reactions Replenishing the TCA Cycle Intermediates}

The increased expression of root cytosolic glutamine synthetase under low P in EC-232019 and not in EC-113396 suggests its role in stress tolerance, which is in agreement with results obtained in creeping bentgrass (Agrostis stolonifera) [45]. Reactions occurring in the glutamine synthetase-glutamine:2-oxoglutarate amidotransferase GS-GOGAT cycle and the glutamate dehydrogenase (GDH) shunt possibly siphoned carbon in amino acids back into the TCA cycle [46]. Argininosuccinate lyase that catalyzes the irreversible breakdown of argininosuccinate to arginine and fumarate increased under low P stress in EC-232019 and not in EC-113396. Fumarate synthesized in this reaction might be available for higher efflux at low $\mathrm{P}$ (evident from Figure 2D) in addition to that produced in the TCA cycle. Arginiosuccinate lyase is also involved in regulating root elongation as reported in rice [47]. Similarly, abundance of fructokinase, a major contributor to glycolytic carbon flux during root growth and development [48] also increased under low P in EC-113396.

\subsubsection{Synthesis of Sulfur Containing Amino Acids}

In addition to regulation of carboxylic acid synthesis, low $\mathrm{P}$ stress in soybean influences several other metabolic pathways. Sustenance of sulfur assimilatory pathway under low P stress is important for recycling of $P_{i}$ from plastidic phospholipids $[49,50]$. Increased abundance of the enzymes cysteine synthase, ATP sulfurylase and S-adenosyl homocysteine synthase is augmented in EC-232019, indicating sustained sulfur assimilation reactions even under low P stress. Methionine synthase, which is also involved in increasing the carbon source under stress as reported in creeping bentgrass [45], increased at low P in EC-113396 but not in EC-232019.

\subsubsection{Other Pathways Affected by Low P Stress}

Abundance of proteins involved in maintenance of cellular homeostasis such as monodehydroascorbate reductase, $80 \mathrm{kDa}$ heat shock cognate protein, $70 \mathrm{kDa}$ heat shock related protein and proteasome subunit alpha and isoflavone reductase increased in EC-232019 under low $P$ stress. Similar responses were observed in isopentenyl transferase (ipt) overexpressed creeping 
bentgrass tolerant to drought stress [45]. Isoflavone reductase-like gene (OsIRL) was found to be involved in scavenging reactive oxygen species in rice [51]. The abundance of actin increased at low P only in EC-232019, while tubulin increased in both genotypes under low P stress. Abundance of actin and tubulin proteins is reported under drought stress, with important roles in determining root cell structure [45]. Subunits of the energy producing protein ATP synthase showed variable response, being increased and decreased under low $\mathrm{P}$ in both genotypes.

\subsection{Future Prospects}

- Differentially abundant proteins with known physiological function may be tested rigorously for imparting $\mathrm{P}$ acquisition efficiency by creating overexpression/knockout mutant lines in soybean or other model systems.

- Hypothetical proteins with putative or unknown function identified in the proteomic analysis may be functionally characterized to ascertain their role(s) under low P stress.

- The identified genotypes may be potential donors in crop improvement programs to develop high-yielding P-efficient cultivars, an asset to low-input sustainable agriculture.

\section{Conclusions}

The proportion of carboxylates (including oxalate, citrate, succinate and fumarate) was highest among root exudates of P-efficient soybean EC-232019. Sustained growth of EC-232019 under low P stress may be attributed to improved root morphological traits and efflux of carboxylates. Key enzymes in the tricarboxylic acid cycle and glycolytic pathways that were induced or suppressed at low P stress showed clear-cut differential regulation among the contrasting genotypes. Enzymes including but not limited to malate dehydrogenase, isocitrate dehydrogenase, phosphoenolpyruvate carboxylase, citrate synthase, glutamine synthetase, argininosuccinate lyase and alcohol dehydrogenase might be implicated in contributing to the additional carbon required for the carboxylate synthesis and efflux in EC-232019 under low P stress. Further, alterations at the transcript and protein level suggest the interdependence of various metabolic pathways conferring higher $\mathrm{P}$ acquisition efficiency to plants under stress.

Supplementary Materials: The following are available online at www.mdpi.com/2073-4425/8/12/341/s1. Figure S1: (A) Digitized root images in two contrasting soybean genotypes grown at sufficient $(250 \mu \mathrm{M})$ and low $(4 \mu \mathrm{M}) \mathrm{P},(\mathrm{B})$ soybean plants immersed in trap solution for root exudate collection, Figure S2: SDS-PAGE gels of total root protein in contrasting soybean genotypes grown at sufficient $(250 \mu \mathrm{M})$ and low $(4 \mu \mathrm{M}) \mathrm{P}$, Figure S3: Two-dimensional gels of total root protein in contrasting soybean genotypes grown at sufficient $(250 \mu \mathrm{M})$ and low $(4 \mu \mathrm{M})$ P, Table S1A: Primers used for RT-qPCR to validate transcript levels of increased proteins at low P $(4 \mu \mathrm{M})$, Table S1B:Primers used for RT-qPCR to validate transcript levels of decreased proteins at low P $(4 \mu \mathrm{M})$, Table S2: Significance of $\mathrm{F}$ values derived from analysis of variance for various physiological traits in contrasting soybean genotypes, Table S3A: Significance of $\mathrm{F}$ values derived from analysis of variance of transcript levels of proteins increased at low P $(4 \mu \mathrm{M})$, Table S3B: Significance of F values derived from analysis of variance of transcript levels of proteins decreased at low $\mathrm{P}(4 \mu \mathrm{M})$, Dataset S1: Annotated spectra of increased proteins at low $\mathrm{P}(4 \mu \mathrm{M})$ in soybean, Dataset S2: Annotated spectra of decreased proteins at low P $(4 \mu \mathrm{M})$ in soybean.

Acknowledgments: This work was funded by Extra Mural Research Division [Grant number 38(1354)/13/EMR-II] of Council of Scientific and Industrial Research, New Delhi, India. Senior Research Fellowship provided by ICAR-IARI, New Delhi to V.K. is sincerely acknowledged. The authors acknowledge the Advanced Instrumentation Research Facility of Jawaharlal Nehru University, New Delhi, for mass spectrometric analysis.

Author Contributions: R.P. conceived and designed the experiments. V.K. carried out the experiments, analyzed data and wrote the manuscript. G.A. and R.K.Y. assisted in carrying out proteomics work.

Conflicts of Interest: The authors declare no conflict of interest. The funding sponsors had no role in the design of the study; in the collection, analyses, or interpretation of data; in the writing of the manuscript, and in the decision to publish the results. 


\section{References}

1. Pandey, R.; Zinta, G.; AbdElgawad, H.; Ahmad, A.; Jain, V.; Janssens, I.A. Physiological and molecular alterations in plants exposed to high $\left[\mathrm{CO}_{2}\right]$ under phosphorus stress. Biotech. Adv. 2015, 33, 303-316. [CrossRef] [PubMed]

2. Jones, D.L.; Dennis, P.G.; Owen, A.G.; van Hees, P.A.W. Organic acid behavior in soils-Misconceptions and knowledge gaps. Plant Soil 2003, 248, 31-41. [CrossRef]

3. Neumann, G.; Romheld, V. The release of root exudates as affected by the plant physiological status. In The Rhizosphere: Biochemistry and Organic Substances at the Soil-Plant Interface; Pinton, R., Varanini, Z., Nannipieri, Z., Eds.; CRC Press: Boca Raton, FL, USA, 2007; pp. 23-71.

4. Lambers, H.; Martinoia, E.; Renton, M. Plant adaptations to severely phosphorus-impoverished soils. Curr. Opin. Plant Biol. 2015, 25, 23-31. [CrossRef] [PubMed]

5. Ryan, P.R.; Delhaize, E.; Jones, D.L. Function and mechanism of organic acid exudation from plant roots. Ann. Rev. Plant Physiol. Mol. Biol. 2001, 52, 527-560. [CrossRef] [PubMed]

6. Lipton, D.S.; Blanchar, R.W.; Blevins, D.G. Citrate, malate and succinate concentration in exudates from P-sufficient and P-stressed Medicago sativa L. seedlings. Plant Physiol. 1987, 85, 315-317. [CrossRef] [PubMed]

7. Ohwaki, Y.; Hirata, H. Differences in carboxylic acid exudation among P-starved leguminous crops in relation to carboxylic acid contents in plant tissues and phospholipid level in roots. Soil Sci. Plant Nutr. 1992, 38, 235-243. [CrossRef]

8. Dong, D.; Peng, X.; Yan, X. Organic acid exudation induced by phosphorus deficiency and/or aluminum toxicity in two contrasting soybean genotypes. Physiol. Plant. 2004, 122, 190-199. [CrossRef]

9. Hoffland, E.; Wei, C.Z.; Wissuwa, M. Organic anion exudation by lowland rice (Oryzasativa L.) at zinc and phosphorus deficiency. Plant Soil 2006, 283, 155-162. [CrossRef]

10. Pandey, R.; Meena, S.K.; Krishnapriya, V.; Ahmad, A.; Kishora, N. Root carboxylate exudation capacity under phosphorus stress does not improve grain yield in green gram. Plant Cell Rep. 2014, 33, 919-928. [CrossRef] [PubMed]

11. Rengel, Z.; Marschner, P. Nutrient availability and management in the rhizosphere: Exploiting genotypic differences. New Phytol. 2005, 168, 305-312. [CrossRef] [PubMed]

12. Roberts, S.K. Plasma membrane anion channels in higher plants and their putative functions in roots. New Phytol. 2006, 169, 647-666. [CrossRef] [PubMed]

13. Ryan, P.R.; Tyerman, S.D.; Sasaki, T.; Furuichi, T.; Yamamoto, Y.; Zhang, W.H.; Delhaize, E. The identification of aluminum-resistance genes provides opportunities for enhancing crop production on acid soils. J. Exp. Bot. 2011, 62, 9-20. [CrossRef] [PubMed]

14. Sasaki, T.; Yamamoto, Y.; Ezaki, B.; Katsuhara, M.; Ahn, S.J.; Ryan, P.R.; Delhaize, E.; Matsumoto, H. A wheat gene encoding an aluminum-activated malate transporter. Plant J. 2004, 37, 645-653. [CrossRef] [PubMed]

15. Ryan, P.R.; Raman, H.; Gupta, S.; Horst, W.J.; Delhaize, E. A second mechanism for aluminum resistance in wheat relies on the constitutive efflux of citrate from roots. Plant Physiol. 2009, 149, 340-351. [CrossRef] [PubMed]

16. Delhaize, E.; Taylor, P.; Hocking, P.J.; Simpson, R.J.; Ryan, P.R.; Richardson, A.E. Transgenic barley (Hordeum vulgare L.) expressing the wheat aluminum resistance gene (TaALMT1) shows enhanced phosphorus nutrition and grain production when grown on an acid soil. Plant Biotech. J. 2009, 7, 391-400. [CrossRef] [PubMed]

17. Liang, C.; Pineros, M.A.; Tian, J.; Yao, Z.; Sun, L.; Liu, J.; Shaff, J.; Coluccio, A.; Kochian, L.V.; Liao, H. Low $\mathrm{pH}$, aluminum, and phosphorus coordinately regulate malate exudation through $G m A L M T_{1}$ to improve soybean adaptation to acid soils. Plant Physiol. 2013, 161, 1347-1361. [CrossRef] [PubMed]

18. Li, K.; Xu, C.; Li, Z.; Zhang, K.; Yang, A.; Zhang, J. Comparative proteome analysis of phosphorus responses in maize (Zea mays L.) roots of wild-type and a low-P-tolerant mutant reveal root characteristics associated with phosphorus efficiency. Plant J. 2008, 55, 927-939. [CrossRef] [PubMed]

19. Yao, Y.; Sun, H.; Xu, F.; Zhang, X.; Liu, S. Comparative proteome analysis of metabolic changes by low phosphorus stress in two Brassica napus genotypes. Planta 2011, 233, 523-537. [CrossRef] [PubMed]

20. Lan, P.; Li, W.; Schmidt, W. Complementary proteome and transcriptome profiling in phosphate-deficient Arabidopsis roots reveals multiple levels of gene regulation. Mol. Cell. Proteom. 2012, 11, 1156-1166. [CrossRef] [PubMed] 
21. Brechenmacher, L.; Lee, J.; Sachdev, S.; Song, Z.; Nguyen, T.H.N.; Joshi, T.; Oehrle, N.; Libault, M.; Mooney, B.; Xu, D.; et al. Establishment of a protein reference map for soybean root hair cells. Plant Physiol. 2009, 149, 670-682. [CrossRef] [PubMed]

22. Sakata, K.; Ohyanagi, H.; Nobori, H.; Nakamura, T.; Hashiguchi, A.; Nanjo, Y.; Mikami, Y.; Yunokawa, H.; Komatsu, S. Soybean Proteome Database: A data resource for plant differential omics. J. Proteome Res. 2009, 8, 3539-3548. [CrossRef] [PubMed]

23. Ohyanagi, H.; Sakata, K.; Komatsu, S. Soybean Proteome Database 2012: Update on the comprehensive data repository for soybean proteomics. Front. Plant Sci. 2012, 3, 110. [CrossRef] [PubMed]

24. Hossain, Z.; Khatoon, A.; Komatsu, S. Soybean proteomics for unravelling abiotic stress response mechanism. J. Proteome Res. 2013, 12, 4670-4684. [CrossRef] [PubMed]

25. Chakraborty, S.; Salekdeh, G.H.; Yang, P.; Woo, S.H.; Chin, C.F.; Gehring, C.; Haynes, P.A.; Mirzaei, M.; Komatsu, S. Proteomics of important food crops in the Asia Oceania region: Current status and future perspectives. J. Proteome Res. 2015, 14, 2723-2744. [CrossRef] [PubMed]

26. Vengavasi, K.; Pandey, R.; Kumar, A. Transcript abundance, enzyme activity and metabolite concentration governing differential carboxylate efflux in soybean under low phosphorus stress. Indian J. Plant Physiol. 2016, 21, 179-188. [CrossRef]

27. Vengavasi, K.; Pandey, R. Root exudation index as a physiological marker for efficient phosphorus acquisition in soybean: An effective tool for plant breeding. Crop Pasture Sci. 2016, 67, 1096-1109.

28. Murphy, J.; Riley, J.P. A modified single solution method for the determination of phosphate in natural waters. Anal. Chim. Acta 1962, 27, 31-36. [CrossRef]

29. Bradford, M.M. Rapid and sensitive method for the quantitation of microgram quantities of protein utilizing the principle of protein-dye binding. Ann. Biochem. 1976, 72, 248-254. [CrossRef]

30. Conesa, A.; Götz, S. Blast2GO: A comprehensive suite for functional analysis in Plant Genomics. Int. J. Plant Genom. 2008, 2008, 619832. [CrossRef] [PubMed]

31. Myhre, S.; Tveit, H.; Mollestad, T.; Laegreid, A. Additional gene ontology structure for improved biological reasoning. Bioinformatics 2006, 22, 2020-2027. [CrossRef] [PubMed]

32. Kanehisa, M.; Goto, S. KEGG: Kyoto Encyclopedia of Genes and Genomes. Nucleic Acids Res. 2000, 28 , $27-30$. [CrossRef] [PubMed]

33. Integrated DNA Technologies. Available online: http://eu.idtdna.com/scitools/Applications/ RealTimePCR. (accessed on 23 November 2015).

34. Schmittgen, T.D.; Livak, K.J. Analyzing real-time PCR data by the comparative CT method. Nat. Protoc. 2008, 3, 1101-1108. [CrossRef] [PubMed]

35. Gahoonia, T.S.; Ali, O.; Sarker, A.; Nielsen, N.E.; Rahman, M.M. Genetic variation in root traits and nutrient acquisition of lentil genotypes. J. Plant Nutr. 2006, 29, 643-655. [CrossRef]

36. Hu, Y.; Ye, Z.; Shi, L.; Duan, H.; Xu, F. Genotypic differences in root morphology and phosphorus uptake kinetics in Brassica napus under low phosphorus supply. J. Plant Nutr. 2010, 33, 889-901. [CrossRef]

37. de Sousa, S.M.; Clark, R.T.; Mendes, F.F.; de Oliveira, A.C.; de Vasconcelos, M.J.V.; Parentoni, S.N.; Kochian, L.V.; Guimaraes, C.T.; Magalhaes, J.V. A role for root morphology and related candidate genes in P acquisition efficiency in maize. Func. Plant Biol. 2012, 39, 925-935. [CrossRef]

38. Lal, M.K. Effect of High [CO2] on Phosphorus Efficiency in Wheat Grown under Phosphorus Stress with Different Sulphur Levels. Master's Thesis, ICAR-Indian Agricultural Research Institute, New Delhi, India, 2015.

39. Raghothama, K.G.; Karthikeyan, A.S. Phosphate acquisition. Plant Soil 2005, 274, 37-49. [CrossRef]

40. Gahoonia, T.S.; Asmar, F.; Giese, H.; Gissel-Nielsen, G.; Nielsen, N.E. Root-released organic acids and phosphorus uptake of two barley cultivars in laboratory and field experiments. Eur. J. Agron. 2000, 12, 281-289. [CrossRef]

41. Gaume, A.; Machler, F.; Leon, D.; Narro, L.; Frossard, E. Low-P tolerance by maize (Zea mays) genotypes: Significance of root growth, and organic acids and acid phosphatase root exudation. Plant Soil 2001, 228, 253-264. [CrossRef]

42. Liao, H.; Wan, H.; Shaff, J.; Wang, X.; Yan, X.; Kochian, L.V. Phosphorus and aluminum interactions in soybean in relation to aluminum tolerance, Exudation of specific organic acids from different regions of the intact root system. Plant Physiol. 2006, 141, 674-684. [CrossRef] [PubMed] 
43. Hernandez, G.; Ramirez, M.; Valdes-Lopez, O.; Tesfaye, M.; Graham, M.A.; Czechowski, T.; Schlereth, A.; Wandrey, M.; Erban, A.; Cheung, F.; Wu, H.C.; et al. Phosphorus stress in common bean: Root transcript and metabolic responses. Plant Physiol. 2007, 144, 752-767. [CrossRef] [PubMed]

44. Plaxton, W.C.; Tran, H.T. Metabolic adaptations of phosphate-starved plants. Plant Physiol. 2011, 156, 1006-1015. [CrossRef] [PubMed]

45. Merewitz, E.B.; Gianfagnam, T.; Huang, B. Protein accumulation in leaves and roots associated with improved drought tolerance in creeping bentgrass expressing an ipt gene for cytokinin synthesis. J. Exp. Bot. 2011, 62, 5311-5333. [CrossRef] [PubMed]

46. Miflin, B.J.; Habash, D.Z. The role of glutamine synthetase and glutamate dehydrogenase in nitrogen assimilation and possibilities for improvement in the nitrogen utilization of crops. J. Exp. Bot. 2002, 53, 979-987. [CrossRef] [PubMed]

47. Xia, J.; Yamaji, N.; Che, J.; Shen, R.F.; Ma, J.F. Normal root elongation requires arginine produced by argininosuccinate lyase in rice. Plant J. 2014, 78, 215-226. [CrossRef] [PubMed]

48. Odanaka, S.; Bennett, A.B.; Kanayama, Y. Distinct physiological roles of fructokinase isozymes revealed by gene-specific suppression of Frk1 and Frk2 expression in tomato. Plant Physiol. 2002, 129, 1119-1126. [CrossRef] [PubMed]

49. Essigmann, B.; Guler, S.; Narang, R.A.; Linke, D.; Benning, C. Phosphate availability affects the thylakoid lipid composition and the expression of $S Q D 1$, a gene required for sulfolipids biosynthesis in Arabidopsis thaliana. Proc. Natl. Acad. Sci. USA 1998, 95, 1950-1955. [CrossRef] [PubMed]

50. Tjellström, H.; Andersson, M.X.; Larsson, K.E.; Sandelius, A.S. Membrane phospholipids as a phosphate reserve: The dynamic nature of phospholipid-to-digalactosyldiacylglycerol exchange in higher plants. Plant Cell Environ. 2008, 31, 1388-1398. [CrossRef] [PubMed]

51. Kim, S.G.; Kim, S.T.; Wang, Y.; Kim, S.K.; Lee, C.H.; Kim, K.K.; Kim, J.K.; Lee, S.Y.; Kang, K.Y. Overexpression of rice isoflavone reductase-like gene (OsIRL) confers tolerance to reactive oxygen species. Physiol. Plant. 2010, 138, 1-9. [CrossRef] [PubMed] 